- IInstitute for

Fiscal Studies

Specific capital, firm insurance, and the dynamics of the postgraduate wage premium

IFS Working Paper W26/19

Ran Gu 


\title{
Specific Capital, Firm Insurance, and the Dynamics of the Postgraduate Wage Premium
}

\author{
Ran $\mathrm{Gu}^{*}$
}

2nd September 2019

\begin{abstract}
Postgraduate degree holders experience lower cyclical wage variation than those with undergraduate degrees. Moreover, postgraduates have more specific human capital than undergraduates. Using an equilibrium search model with long-term contracts and imperfect monitoring of worker effort, this paper attributes the cyclicality of the postgraduate-undergraduate wage gap to the differences in specific capital. Imperfect monitoring creates a moral hazard problem that requires firms to pay efficiency wages. More specific capital leads to lower mobility, thereby alleviating the moral hazard and improving risk-sharing. Estimates reveal that specific capital explains the differences both in labour turnover and in wage cyclicality across education groups.
\end{abstract}

${ }^{*}$ Department of Economics, University of Essex, CO4 3SQ, UK, email: ran.gu@essex.ac.uk and Institute for Fiscal Studies. I am grateful for the generous support of Richard Blundell, Jeremy Lise, and Fabien Postel-Vinay. I am also thankful for the invaluable advice of Arun Advani, Ben Etheridge, Carlos Carrillo-Tudela, Alex Clymo, Melvyn Coles, Søren Leth-Petersen, Attila Lindner, Costas Meghir, Andreas Müller, Imran Rasul, Jean-Marc Robin, Uta Schönberg, Eric Smith and seminar participants at Bristol, Essex, EIEF, Royal Holloway, IFS, and UCL for helpful comments and suggestions. 


\section{Introduction}

Firms can provide employment contracts to insure workers from aggregate shocks (Azariadis, 1975; Beaudry and DiNardo, 1991). Significant research efforts have been devoted to characterizing optimal contracts in frictional labour markets (Burdett and Coles, 2003; Rudanko, 2009; Menzio and Shi, 2011). While it has been recognized that workers with more specific human capital face lower cyclical variation in employment than unskilled workers (Cairó and Cajner, 2016), little evidence is available on the relative variation of their wages. In this paper, I build an equilibrium search model to study the impact of specific human capital on wage variation over the business cycle. Then, I apply this model to explain novel stylised facts about the cyclicality of the postgraduate wage premium.

Beginning with the data, can education provide shelter against wage shocks over the business cycle? As the employment share held by postgraduates has doubled since 1980, I compare postgraduates to those with only undergraduate degrees and document a new result: In the US, the postgraduate-undergraduate wage premium is counter-cyclical. ${ }^{1}$ To illustrate, Figure 1 plots the detrended real GDP and the postgraduate wage premium. $^{2}$ The postgraduate wage premium increases substantially during all recent recessions, and its correlation with real GDP is -0.47 . Table 1 reports that when real GDP goes up by $1 \%$, the median postgraduate wage increases by $0.34 \%$, and the median undergraduate wage increases by $0.58 \%$, indicating that postgraduate wages respond less to business cycle shocks than undergraduate wages. ${ }^{3}$ Table 1 also shows that both the college-noncollege

\footnotetext{
${ }^{1}$ Postgraduate degrees include masters, Ph.D., and professional degrees. Lindley and Machin (2016) document that in 2012 nearly 15\% of the adult workforce, or $40 \%$ of all college graduates, have a postgraduate degree. As I discuss further in my review of the literature, the existing literature analyzes the cyclicality of the college-noncollege wage premium, and finds it to be acyclical.

${ }^{2}$ See Appendix A for a description of the data.

${ }^{3}$ In terms of means, when real GDP goes up by $1 \%$, the average postgraduate wage increases by $0.25 \%$, and the average undergraduate wage increases by $0.85 \%$.
} 
wage premium and the undergraduate-noncollege wage premium are largely acyclical. ${ }^{4}$ Therefore, education can provide insurance against cyclical wage shocks only if a postgraduate degree is obtained.

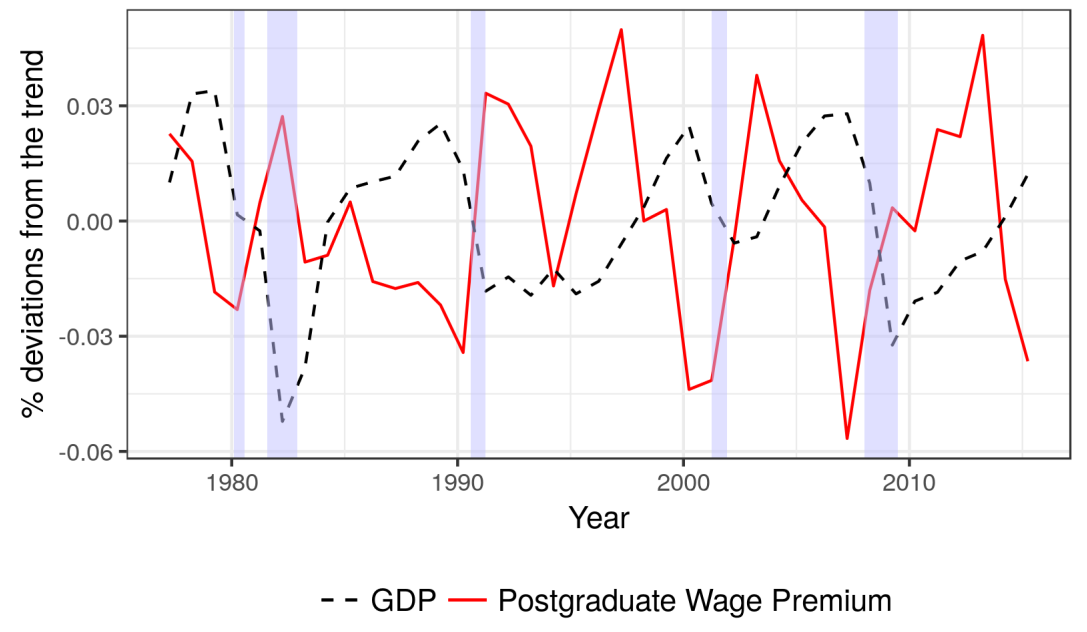

Figure 1: Detrended Real GDP and Postgraduate Wage Premium Current Population Survey March Supplement (March CPS) 1976-2016, males, aged 26-64. NBER dated recessions are shaded. Series are logged and detrended using a Hodrick-Prescott (HP) filter with parameter 100.

Furthermore, I find that the difference in wage cyclicality between postgraduates and undergraduates is significant for workers with a long tenure in a given job, but not for new hires. ${ }^{5}$ As workers' job tenure is the generally used proxy for specific human capital (Altonji and Shakotko, 1987), I argue that this phenomenon occurs because experienced postgraduates accumulate more specific capital in their jobs than their undergraduate degree-

\footnotetext{
${ }^{4}$ The undergraduate-noncollege wage premium is weakly pro-cyclical in the mean, while it is acyclical in the median and the top $25 \%$. As is argued by Lindquist (2004), the median wage premium is a more suitable measure of the correlation between output and the wage premium than the mean wage premium, because composition bias and top-coding have a smaller impact on the median wage premium.

${ }^{5}$ I show that the counter-cyclical postgraduate wage premium is due neither to cyclical changes in the composition of the workforce, nor to postgraduates and undergraduates sorting into different industries and occupations.
} 
Table 1: Elasticity with respect to GDP

\begin{tabular}{lcccccc}
\hline & & \multicolumn{2}{c}{ Wage } & \multicolumn{3}{c}{ Wage Premium } \\
& Postgrad & Undergrad & Noncollege & $\frac{\text { Postgrad }}{\text { Undergrad }}$ & $\frac{\text { Undergrad }}{\text { Noncollege }}$ & $\frac{\text { College }}{\text { Noncollege }}$ \\
\hline Median & .34 & .58 & .57 & -.24 & .01 & .03 \\
& $(.14)$ & $(.16)$ & $(.12)$ & $(.14)$ & $(.14)$ & $(.13)$ \\
Top25\% & .04 & .71 & .53 & -.67 & .18 & -.03 \\
& $(.19)$ & $(.15)$ & $(.11)$ & $(.16)$ & $(.12)$ & $(.12)$ \\
Mean & .25 & .85 & .50 & -.60 & .35 & .12 \\
& $(.18)$ & $(.17)$ & $(.12)$ & $(.18)$ & $(.15)$ & $(.13)$ \\
\hline
\end{tabular}

Wages are deflated to constant 2000 dollars. College $=$ undergraduates + postgraduates.

holding counterparts, and thus, they are offered contracts with smoother wages. Since new hires have not yet built any specific capital, the difference in wage cyclicality between postgraduates and undergraduates is small. I provide empirical evidence showing postgraduates have more specific capital in two dimensions: the size of specific capital that new hires have to build and the time needed for this process. First, with regard to the time dimension, I construct a new measurement using the data on the adaptation period in a new job: newly hired postgraduates need 58.5 weeks to become fully competent, twice as long as the time needed by undergraduates. Second, with regard to the size dimension, Dustmann and Meghir (2005) argue that more specific capital leads to larger wage losses from exogenous job displacement. I show that displaced postgraduates suffer an average wage loss of $17.8 \%$, twice as much of a loss as undergraduates.

To understand how specific capital affects labour turnover and wage cyclicality, I develop a directed search model of wage contracting and firm commitment, based on the work of Tsuyuhara (2016) and Lamadon (2016). I depart by adding specific human capital and aggregate shocks to matches. I assume new hires have zero endowment of any specific capital, which they obtain through a period of job adaptation. In the model, risk-neutral firms provide long-term contracts, and risk-averse workers choose their effort level 
to avoid job separation. If effort were observable, because of the difference in risk aversion, firms would bear all the risk, offer constant wages, and prescribe constant effort. I assume worker effort is unobserved by firms (Azariadis, 1975). With this assumption, workers might shirk. Firms pay efficiency wages to induce them to provide the optimal level of effort.

The optimal contract is such that wage changes track aggregate productivity shocks: When aggregate productivity increases, firms increase wages of workers to incentivize them to make a greater effort. I show that the effort level of skilled workers increases with specific human capital: After gaining specific capital, skilled workers have strong incentives to keep their jobs longer. As these incentives increase with the level of specific capital, skilled workers with more specific capital make a greater effort to avoid job separation.

I further show that wage smoothing of skilled workers increases with specific capital. On the one hand, as skilled workers with more specific capital are less likely to leave their current jobs, they will value more about firms' promises of future wage changes. As wage changes becomes more effective in motivating workers, firms do not need to give workers a lot of incentives. Intuitively, firms do not have to increase wages to keep them in booms. On the other hand, as the level of effort increases with the level of specific capital, the response of effort to increased incentives decreases. Then, it becomes increasingly costly for firms to provide incentives for worker effort. Firms face the trade-off between insurance and incentives. As more specific capital increases both the effectiveness and the marginal cost of providing incentives, it becomes optimal for firms to provide more insurance to workers with more specific capital, i.e. smaller wage changes caused by changes in aggregate productivity.

Although the model is parsimonious, it can endogenously generate the differences in both labour turnover and wage cyclicality across education groups, given the observed empirical differences in specific human capital. 
Additionally, my paper implies that lower educated workers, and even undergraduates, are unlikely to receive much insurance from firms, thereby, increasing the demand for social insurance among this group. I conduct a counterfactual policy experiment to raise the unemployment insurance (UI) replacement rate by 20\%. I find that this policy increases wage cyclicality, indicating UI crowds out the implicit insurance provided by firms. However, the effect is less pronounced for lower educated workers than for postgraduates. Lower educated workers have a higher welfare gain than postgraduates from such a policy, which supports the argument for a lower UI replacement rate for postgraduates.

\section{Related Literature}

A large literature has studied the extent to which workers can insure themselves against uncertain labour income (see e.g. Krueger and Perri, 2005, 2006; Heathcote, Storesletten and Violante, 2005; Blundell, Pistaferri and Preston, 2008). This paper explores where income shocks arises from in the first place, and argues that postgraduates get more firm insurance than other education groups because they have more specific capital.

The theoretical literature on how specific capital affects wage cyclicality is inconclusive. Azariadis (1976) studies long-term contracts with commitment and implies that firms are more willing to offer constant wages to workers with more specific capital. On the other hand, Hashimoto (1975) and Raisian (1979) study implicit contracts with lack of commitment and imply that workers with more specific capital accept higher cyclical fluctuations in wages in return for higher employment security. My work extends this literature by showing that, in an economy with search frictions and firm commitment, workers with more specific capital are offered contracts with smoother wages.

In the search literature, Hudomiet (2015) and Cairó and Cajner (2016) evaluate the effect of specific capital on employment and labour turnover. To my knowledge, the current paper is the first to quantify the effect of specific 
capital on both labour turnover and wage cyclicality.

This paper contributes to the literature that studies the cyclicality of education wage premium. Keane and Prasad (1993) and Lindquist (2004) compare wage cyclicality between noncollege workers and college graduates, a group which includes both undergraduates and postgraduates. They find that both types of workers experience the same degree of cyclical wage shocks, i.e. that the college wage premium is acyclical. I confirm their result, but show that the cyclicality emerges once undergraduates and postgraduates are considered separately.

\section{Outline}

Section 2 and 3 provide empirical evidence on wage cyclicality and specific capital. Section 4 presents the equilibrium search model. In Section 5, I outline the estimation strategy, discuss the identification, and report the estimation results. In Section 6, I analyze the estimated model and report the counterfactual simulations. Section 7 evaluates the counterfactual policy. Section 8 concludes.

\section{Empirical Evidence on Wage Cyclicality}

In this section, I use individual-level data to compare the wage cyclicality between postgraduates and undergraduates, controlling for observed characteristics. Then, I study the relationship between the cyclicality of the postgraduat wage premium and job tenure.

\subsection{Regression of Wage on Degree Interaction}

To estimate the effects of postgraduate degree on the wage cyclicality, I follow Keane and Prasad (1993) and run the regression of log real hourly wage 


$$
\ln W_{i t}=\theta P G_{i t}+\alpha U_{t}+\gamma P G_{i t} \times U_{t}+X_{i t} \beta+\varepsilon_{i t}
$$

where $P G_{i t}$ is a postgraduate degree dummy, which equals 1 if the worker has a postgraduate degree and 0 if he only has an undergraduate degree. I use the aggregate unemployment rate in the economy, $U_{t}$, as an indicator of the business cycle. ${ }^{6} \alpha$ measures the cyclicality of the undergraduate wage. For instance, a negative estimate of $\alpha$ would imply that the average real wage of undergraduates declines when the aggregate unemployment rate rises, i.e. the undergraduate wage is pro-cyclical. The coefficient $\gamma$ on the interaction term $P G_{i t} \times U_{t}$ captures the difference between the cyclicality of the postgraduate wage and the undergraduate wage, and $\alpha+\gamma$ measures the cyclicality of the postgraduate wage. A positive estimate of $\gamma$ would indicate a counter-cyclical postgraduate wage premium - the premium increases when the unemployment rate rises. $X_{i t}$ is a vector of observables including state dummies, a race dummy, a marriage dummy, a cubic age trend and a quartic time trend.

\section{Empirical Results}

Table 2 presents the estimates from regression (1). I use the 1976-2016 March CPS and restrict the sample to males aged 26-64 not self-employed. I further restrict the above sample to postgraduates and undergraduates only. The sample size is 364,864 individuals. Following Robin (2011), the unemployment rate is successively log-transformed, HP-filtered and exponentiated. I HP-filter the annual series with a conventional smoothing parameter 100 . The results are robust to the detrending method. ${ }^{7}$

The first column of Table 2 shows the regression result on log real hourly

\footnotetext{
${ }^{6}$ The results are not affected by choice of the business cycle. See the discussion in the next section.

${ }^{7} \mathrm{I}$ also detrend the unemployment rate using a cubic trend and obtain very similar results. See column (2) of Table 13 in Appendix B.1.
} 
Table 2: Regression on Degree Interaction

\begin{tabular}{lcccc}
\hline $\begin{array}{l}\text { Data } \\
\text { Method }\end{array}$ & \multicolumn{3}{c}{ March CPS $76-16$} & PSID 85-15 \\
Dependent & lnWage & lnHour & lnEarnings & lnWage \\
\hline$U R A T E(\alpha)$ & -.0124 & -.0064 & -.0188 & -.0125 \\
& $(.0012)$ & $(.0007)$ & $(.0015)$ & $(.0032)$ \\
$P G \times U R A T E(\gamma)$ & .0086 & .0035 & .0121 & .0120 \\
& $(.0021)$ & $(.0011)$ & $(.0024)$ & $(.0062)$ \\
\hline$\alpha+\gamma$ & -.0038 & -.0029 & -.0067 & -.0005 \\
& $(.0017)$ & $(.0009)$ & $(.0019)$ & $(.0053)$ \\
\hline Observations & & 364,864 & & 12,692 \\
\hline
\end{tabular}

wages. Hourly wages are computed as annual labour earnings divided by annual hours, and are deflated to constant 2000 dollars. The estimated coefficient $\alpha$ on the unemployment rate is -0.0124 (s.e. 0.0012 ), indicating that a 1 percentage point rise in the aggregate unemployment rate causes a $1.24 \%$ decline in the real wage for undergraduates. Thus, the undergraduate wage is strongly pro-cyclical. The estimated coefficient $\gamma$ on the interaction term $P G_{i t} \times U_{t}$ is 0.0086 (s.e. 0.0021), indicating that when the unemployment rate goes up by 1 percentage point in a downturn, postgraduates face a $0.86 \%$ increase in their real wage relative to that of undergraduates. Therefore, the postgraduate wage premium is counter-cyclical. The sum of the coefficients $\alpha$ and $\gamma$ is -0.0038 (s.e. 0.0017 ), indicating that a 1 percentage point rise in the unemployment rate causes a $0.38 \%$ decline in the postgraduate wage, which is less pro-cyclical than the undergraduate wage. I also experiment with other indicators of the business cycle, such as log real GDP. I find that when real GDP increases by $1 \%$, the average real hourly wage for postgraduates increases by $0.403 \%$ and that for undergraduates increases by $0.988 \%$. See column (1) of Table 13 in Appendix B.1 for the estimates. Column (3)-(5) of the same table presents robustness checks, including median regression and regression by age groups, all confirming my finding that the postgraduate 
wage is in fact less pro-cyclical than the undergraduate wage. ${ }^{8}$

\section{Hours and Earnings}

The second column of Table 2 provides estimates of the cyclicality of annual hours worked. The estimation framework is identical to that used for real hourly wages (Equation 1). The coefficient on $U_{t}$ is -0.0064 (s.e. 0.0007) and the coefficient on $P G_{i t} \times U_{t}$ is 0.0035 (s.e. 0.0011). Thus, for postgraduates, annual hours worked are less procyclical than those for undergraduates. The difference in the cyclicality of hours between undergraduates and postgraduates is smaller than that of wages. The third column of Table 2 shows estimates of cyclicality of annual labour earnings. When the unemployment rate goes up by 1 percentage point, the real earnings of undergraduates fall by $1.88 \%$, and those of postgraduates fall by $0.67 \%$. Postgraduate earnings are less pro-cyclical than undergraduate earnings. In conjunction, these results suggest that postgraduates have smoother wages, hours, and earnings than undergraduates.

\section{Selection Bias}

The typical selection bias problem in this type of analysis is: undergraduates are more likely to be unemployed than postgraduates during recessions, so the relative wage of undergraduates increases mechanically. This is contrary to my finding. Furthermore, the unemployment rates for both undergraduates and postgraduates are less than 3\% (Table 6), which illustrates the limited effect of the selection bias problem. However, to eliminate such systematic selection regardless, I focus on job stayers - workers who stayed in the same job last year, did not look for work during that period, and worked for 52 weeks. This essentially compares average postgraduates with good

\footnotetext{
${ }^{8}$ Figure 4 in Appendix B.3 plots wage growth rates in booms and recessions. Undergraduates have a larger wage growth rate than postgraduates in booms and a smaller wage growth rate than postgraduates in recessions.
} 
undergraduates, so the estimated coefficient should be smaller. Column (6) of Table 13shows that the estimated coefficient $\gamma$ shrinks slightly to 0.0069 . To further support my findings, I run Heckman (1979) selection model with a first-stage probit employment equation. ${ }^{9}$ The estimates are in Column (7) of same table, which is similar to the baseline.

\section{Industries and Occupations}

Table 14 in Appendix B.2 presents the estimates from the wage regression by major industries and occupations. This can be used to check whether this phenomenon occurs because postgraduates and undergraduates sort into different industries and occupations, which are subject to different cyclical shocks in productivity. I find that the postgraduate wage premium is countercyclical in all major industries and in 4 out of 7 major occupations. ${ }^{10}$ In addition, I also check how the coefficient $\gamma$ on $P G_{i t} \times U_{t}$ shrinks after controlling for interactions between $U_{t}$ and industries and occupations in Table 15 in the same appendix. The more this coefficient shrinks, the more industries and occupations can explain the counter-cyclicality postgraduate wage premium. I find that $\gamma$ shrinks to 0.0065 and 0.0052 after controlling for 3-digit industries and occupations respectively.

\section{Individual Fixed-Effects}

I also run regression 1 with individual fixed-effects controlling for a cubic age trend and a quartic time trend. I use the 1985-2015 Panel Study of Income Dynamics (PSID) and restrict the sample to male heads aged 26-64 not self-employed. The last column of Table 2 presents the estimates. The estimated coefficient $\alpha$ on the unemployment rate $U_{t}$ is -0.0125 (s.e. 0.0032 )

\footnotetext{
${ }^{9}$ The variables included in the first-stage employment equation but excluded from wage equation are: number of own children in the household, number of own children under age 5 in the household, and age of youngest own child in the household.

${ }^{10}$ These occupations include Managerial, Professional Specialty, Technical, and Sales, which added up to $82 \%$ of all college graduates.
} 
indicating that a 1 percentage point rise in the aggregate unemployment rate causes a $1.25 \%$ decline in the real hourly wage for undergraduates. ${ }^{11}$ The estimated coefficient $\gamma$ on the interaction term $P G_{i t} \times U_{t}$ is 0.0120 (s.e. 0.0062 ) indicating that when the unemployment rate goes up by 1 percentage point, postgraduates face a $1.2 \%$ increase in their real wage relative to that of undergraduates, which confirms that the postgraduate wage premium is counter-cyclical.

\subsection{Job Tenure and Specific Capital}

Is there a link between counter-cyclical postgraduate wage premium and job tenure? I test for it using PSID, which is particularly advantageous here because of the information it provides on the length of uninterrupted tenure on the current job. I run the following fixed-effects regression of log wage on interactions between $U_{t}, P G_{i t}$ and length of tenure

$$
\begin{aligned}
\ln W_{i t} & =\text { ShortTenure }_{i t} \times\left(\alpha_{1} U_{t}+\gamma_{1} P G_{i t} \times U_{t}\right) \\
& +\left(1-\text { ShortTenure }_{i t}\right) \times\left(\alpha_{2} U_{t}+\gamma_{2} P G_{i t} \times U_{t}\right)+X_{i t} \beta+\mu_{i}+\varepsilon_{i t}
\end{aligned}
$$

where ShortTenure it $_{\text {is }}$ is a dummy on the length of tenure, which equals 1 if the worker has at most $\kappa$ years of uninterrupted tenure on the current job and equals 0 if he has a longer tenure. $\mu_{i}$ stands for unobserved individual-specific characteristics that are fixed over time. $X_{i t}$ includes a cubic age trend and a quartic time trend. For new hires, the coefficient $\alpha_{1}$ measures the cyclicality of the undergraduate wage, and $\gamma_{1}$ measures the difference in wage cyclicality between postgraduates and undergraduates. For workers with a long tenure,

\footnotetext{
${ }^{11}$ Using 1968-1992 PSID, Swanson (2007) regress log real hourly wage on the unemployment rate without distinguishing education levels. He finds that a 1 percentage point rise in the aggregate unemployment rate causes a $1.22 \%$ decline in the real wage, which is of the similar magnitude as my estimates.
} 
the coefficients $\alpha_{2}$ measures the cyclicality of the undergraduate wage, and $\gamma_{2}$ measures the difference in wage cyclicality between postgraduates and undergraduates.

I restrict the sample to male heads aged 26-64 not self-employed. First, following Altonji and Williams (2005), I set ShortTenure as, at most, 1.5 years of tenure. The estimates are presented in the Column " $\kappa=1.5$ " of Table 3. For new hires, the estimated coefficient $\gamma_{1}$ on the interaction term $P G_{i t} \times U_{t}$ has the positive sign but is not significant. For workers with a long tenure, the estimated coefficient $\gamma_{2}$ is significantly positive, indicating that postgraduates have smaller wage cyclicality than undergraduates. $\gamma_{2}$ is significantly larger than $\gamma_{1}$ indicates that the difference in wage cyclicality between postgraduates and undergraduates is higher for workers with a long tenure than new hires. Then, in the Column " $\kappa=2$ " and $\kappa=2.5$ ", I set ShortTenure as, at most, 2 years of tenure and 2.5 years of tenure respectively. The results are not changed.

A worker's job tenure is the generally used proxy for specific human capital (Altonji and Shakotko, 1987; Topel, 1991). Thus, this phenomenon is consistent with a story of specific capital: Postgraduates accumulate more specific capital in their jobs than undergraduates. As new hires have not yet built any specific capital, the difference in wage cyclicality between postgraduates and undergraduates is small. As workers with a long tenure have accumulated specific human capital, the difference in wage cyclicality is large.

\section{Empirical Evidence on Specific Capital}

In previous sections, I showed that postgraduates have smoother wages than undergraduates over the business cycle, and that this effect is stronger for workers with a long tenure than new hires. My theory for this phenomenon is that postgraduates have more specific capital which reduces their wage cyclicality. Specific capital has two dimensions: the size of the specific capital 
Table 3: Fixed-effect Regressions by Job Tenure

\begin{tabular}{lccc}
\hline lnWage & $\kappa=1.5$ & $\kappa=2$ & $\kappa=2.5$ \\
\hline ShortTenure & & & \\
URATE $\left(\alpha_{1}\right)$ & -.0172 & -.0151 & -.0160 \\
& $(.0075)$ & $(.0065)$ & $(.0062)$ \\
$P G \times U R A T E\left(\gamma_{1}\right)$ & .0052 & .0059 & .0052 \\
& $(.0068)$ & $(.0066)$ & $(.0066)$ \\
$1-$ ShortTenure & & & \\
URATE $\left(\alpha_{2}\right)$ & -.0118 & -.0123 & -.0122 \\
& $(.0035)$ & $(.0035)$ & $(.0036)$ \\
PG $\times$ URATE $\left(\gamma_{2}\right)$ & .0111 & .0114 & .0118 \\
& $(.0062)$ & $(.0062)$ & $(.0062)$ \\
\hline$\gamma_{2}-\gamma_{1}$ & .0059 & .0054 & .0066 \\
& $(.0030)$ & $(.0027)$ & $(.0027)$ \\
\hline Observations & & 12,692 & \\
Workers & & 1,804 & \\
\hline
\end{tabular}

PSID 1985-2015, males heads, aged 26-64, not self-employed. " $\kappa=1.5 "$ : ShortTenure is set as, at most, 1.5 years of tenure. " $\kappa=2$ ": ShortTenure is set as, at most, 2 years of tenure. " $\kappa=2.5$ ": ShortTenure is set as, at most, 2.5 years of tenure. Controls: a cubic age trend and a quartic time trend.

that new hires have to build and the time needed for this process. In what follows, I show that postgraduates have more specific capital in these two dimensions.

\subsection{Job Adaptation}

First, I study the time it takes to accumulate specific capital. I construct a new measurement in a US employer survey - the Multi-City Study of Urban Inequality (MCSUI), which measures how long it takes new hires to be fully competent in their jobs. I call this measurement the adaptation period in a new job.

The MCSUI was conducted between 1992 and 1994, in the middle of the time period with which this paper is concerned. The survey asked employers 
a series of specific questions about the last new employee the company hired. One of these questions proves particularly useful for analyzing adaptation duration. The question reads "How many weeks does it take the typical employee in this position to become fully competent in it?" Table 4 provides descriptive statistics on this measure of the time dimension of specific capital. The results show a considerable difference between postgraduates and undergraduates: a newly hired postgraduate needs 58.5 weeks on average to become fully competent, which is twice as long as the time needed for a newly hired undergraduate (29.2 weeks). The difference is significant at the one percent level. Thus, postgraduates have a longer duration of job adaptation than undergraduates. A newly hired noncollege worker needs 22.5 weeks to become fully competent, which is about $80 \%$ of the time needed for a newly hired undergraduate. Therefore, the difference in the duration of job adaptation between postgraduates and undergraduates is much larger than that between undergraduates and noncollege workers.

Table 4: Job Adaptation Duration by Education

\begin{tabular}{lccc}
\hline Education & Noncollege & Undergrad. & Postgrad. \\
\hline Weeks until competent & 22.5 & 29.2 & 58.5 \\
& $(.88)$ & $(2.32)$ & $(8.98)$ \\
Observations & 2566 & 515 & 159 \\
\hline
\end{tabular}

MCSUI 1992-1994.

\subsection{Wage Loss from Job Displacement}

With regard to the size dimension, Dustmann and Meghir (2005) argue that more specific capital leads to larger wage losses from exogenous job displacement. I examine this implication using the 1994-2008 Displaced Workers Survey (DWS), which is a supplement to the CPS. The DWS identifies displaced workers who have been separated from their employers for reasons of 
slack work, plant closings, and abolished jobs - reasons which have been taken by the literature to instrument for "exogenous" layoffs. The DWS records information on earnings on both the displaced and current job. I construct a sample of male workers who were involuntarily displaced from a full-time job last year and who were reemployed in a full-time job at the time of their interview.

In Table 5, I show the change in log wages across the current job and the displaced job. The resulting statistics represent the fraction of a typical worker's wage that would be lost if he was exogenously removed from his current match and left to find a new job. Percent losses in wages are significant from zero for all education levels, showing a sizable productivity gap between new hires and experienced workers. The percent losses in wages are significantly larger for postgraduates than undergraduates at the ten percent level, and the difference is substantial: -0.178 for postgraduates, twice as large as that for displaced undergraduates $(-0.086)$. The difference between undergraduates and noncollege workers is not significant. In Section 4, by targeting the percent losses in wages for displaced workers by education, I estimate the initial productivity gaps of new hires in my model, which is indeed higher for postgraduates than for undergraduates.

Table 5: Wage Loss from Job Displacement by Education

\begin{tabular}{lccc}
\hline Education & Noncollege & Undergrad. & Postgrad. \\
\hline $\mathbb{E}\left(\log w_{t}-\log w_{t-1}\right)$ & -.086 & -.086 & -.178 \\
& $(.013)$ & $(.030)$ & $(.060)$ \\
Observations & 2576 & 543 & 210
\end{tabular}

DWS 1994-2008, males who were involuntarily displaced from a full-time job last year and are reemployed in a full-time job now. 


\subsection{Worker Flows}

Table 6 shows unemployment rates and worker flows for males aged 26-64. Postgraduates have lower unemployment rate than undergraduates. Their job separation rate is $0.46 \%$, which is $50 \%$ lower than that of undergraduates. The job finding rate of postgraduates is $24.5 \%$, which is $7.3 \%$ lower than that of undergraduates, and the job-to-job transition rate of postgraduates is $1.78 \%$, which is $8.4 \%$ lower than that of undergraduates. Thus, postgraduates are less mobile (lower probabilities of job separation, finding a job, and transitioning to another job) than undergraduates, indicating that workers with more specific capital have lower outside options.

Table 6: Unemployment Rates and Monthly Worker Flows

\begin{tabular}{lcc}
\hline Education & Postgrad. & Undergrad. \\
\hline Unemployment rate & $2.05 \%$ & $2.90 \%$ \\
Job separation rate & $0.46 \%$ & $0.69 \%$ \\
Job finding rate & $24.5 \%$ & $26.3 \%$ \\
Job-to-job transition rate & $1.78 \%$ & $1.93 \%$ \\
transition rate uses Monthly CPS $1994-2014$. & Other variables use \\
PS 1979-2014.
\end{tabular}

Monthly CPS 1979-2014.

\section{The Contracting Model of Asymmetric In- formation}

In this section, I develop an equilibrium search model with long-term contracts, imperfect monitoring of worker effort, and accumulation of specific human capital. I use it to evaluate the impact of specific capital on wage cyclicality by education. ${ }^{12}$ In the model, the amount of specific capital is

\footnotetext{
${ }^{12}$ Mortensen and Pissarides (1994) type search models have been used extensively to model long-term relationships between workers and firms. These models typically assume
} 
equal to the productivity gap between trainees (new hires) and skilled workers. Trainees obtain specific capital through a period of job adaptation. I assume risk-averse workers and risk-neutral firms, which make long-term contracts optimal. ${ }^{13}$ Imperfect monitoring creates a moral hazard problem that requires firms to pay efficiency wages. Job search is directed, and the equilibrium is block-recursive, such that individuals' optimal decisions and optimal contracts are independent of the distribution of workers.

\subsection{The Environment}

Time is discrete, indexed by $t$, and continues forever. Workers are characterized in terms of their education: either noncollege (NC), undergraduate (BA), or postgraduate (PG). Workers in each education group possess a certain amount of general human capital, denoted by $h \in\left\{h_{N C}, h_{B A}, h_{P G}\right\}$. I follow the standard approach in search and matching literature by assuming that a firm is a single-worker production unit. Workers are initially unskilled in matches. Let $s \in\{0,1\}$ denotes a worker's level of specific capital in the match, where $s=1$ represents a worker possessing specific capital and $s=0$ represents a trainee (new hire) without specific capital. Trainees obtain specific capital through a period of job adaptation. In each period, a trainee may upgrade to a skilled worker with probability $\phi^{h}$. Then $1 / \phi^{h}$ yields the average duration of job adaptation. I let $\tau^{h}$ measures the extent of the productivity gap between trainees and skilled workers. Note that $\phi^{h}$ and $\tau^{h}$ depend on the education level $h$.

Aggregate productivity $z_{t}$ evolves as a first-order Markov chain with transition probabilities $\pi\left(z_{t+1} \mid z_{t}\right)$. In aggregate state $z$, a match between a firm

continual Nash wage bargaining, which would impose transmission of productivity shocks to wages by construction. Besides, as workers are usually risk-neutral in these models, they do not care about wage insurance. Allowing risk-aversion will make these models as complicated as mine.

${ }^{13}$ This assumption is based on the arguments that entrepreneurs are less risk-averse than workers, and their risk can be insured through better access to asset markets. 
and a worker of education $h$ produces

$$
y^{h}(s, z)=h z-\tau^{h}(1-s)
$$

In other words, when the worker is skilled $s=1$, the output from the match is $h z$, whereas a trainee produces $h z-\tau^{h}$.

Workers are risk-averse. They are endowed with one unit of labour each period, which they supply inelastically to the firms for a wage $w_{t}$. There are no asset markets or storage technology, and so the worker's consumption each period equals his wage. ${ }^{14}$ Workers also choose the level of effort $e_{t}$ to avoid job separation.

Assumption 1. The level of effort $e_{t}$ equals the probability that the job continues to exist next period.

With probability $1-e_{t}$, the worker becomes unemployed. This captures the idea that a negligent worker might lose a client or break the machine and cause the job to disappear. Preferences of the worker are

$$
\mathbb{E} \sum_{t=0}^{\infty} \beta^{t}\left[\frac{w_{t}^{1-\gamma}-1}{1-\gamma}-c\left(e_{t}\right)\right]
$$

where he has constant relative risk aversion preference over consumption, and the effort cost function $c($.$) is differentiable, increasing, strictly convex,$ and satisfies standard Inada conditions so that effort is interior. Unemployed workers receive flow value of unemployment $b^{h}$.

In the beginning of each match, a risk-neutral firm offers a long-term contract to a risk-averse worker. The contract specifies wages and recommended

\footnotetext{
${ }^{14} \mathrm{~A}$ search model combing saving, long-term contracts is very complicated in a business cycle setting, because job search depends on wealth. In the setting of wage posting, it requires firms to post jobs depending on wealth. But this is an interesting extension, and I will explore it in future research. The point I wish to emphasize in this paper is that workers need less social insurance if there is more firm insurance. Then allowing them to save will make them need even less social insurance.
} 
effort for all continuation histories. Let $x_{\tau}=\left(s_{\tau}, z_{\tau}\right)$ be the state of the match at period $\tau$. History up to period $\tau$ is denoted by $x^{\tau}=\left(x_{1}, \ldots, x_{\tau}\right)$. Then the contract is a function

$$
\sigma=\left\{w_{\tau}\left(x^{\tau}\right), e_{\tau}\left(x^{\tau}\right)\right\} \text { for all } x^{\tau}
$$

where $w_{\tau}$ is the wage and $e_{\tau}$ is the recommended effort.

The optimal contract depends crucially on the observability of the effort level. If effort were observable, because of the difference in risk aversion between firms and workers, the problem would be purely one of efficient risk sharing in which firms would bear all the risk, offer constant wages, and prescribe constant effort (Azariadis, 1975).

Assumption 2. The level of effort $e_{t}$ is unobserved by firms.

As cost of effort enters negatively in his utility function, the worker might shirk his effort. Then, firms have to adjust wages to provide incentives. Thus, the moral hazard problem requires firms to pay efficiency wages.

Contracts can be formulated recursively by introducing an additional state variable, the promised value $V$ (Spear and Srivastava, 1987), which is the expected discounted future value that the firm promised to deliver to the worker from this period onwards. At each state $(h, s, z, V)$, the firm

chooses $\left\{w,\left\{V_{s^{\prime} z^{\prime}}^{h}\right\}, e\right\}$. Here $w$ is the current wage, $\left\{V_{s^{\prime} z^{\prime}}^{h}\right\}$ is the expected discounted value promised for each realization of aggregate state $z^{\prime}$ and skill type $s^{\prime}$ next period, and $e$ is the recommended effort level.

\subsection{Effort Choice and Firm Profit}

An employed worker optimally chooses effort $e$ prescribed by the contract. Let $U_{z}^{h}$ be the value of unemployment for a worker of education level $h$ at aggregate state $z$. The incentive-compatibility constraint for a worker of skill 
type $s$ and education level $h$ at aggregate state $z$ is

$$
e \in \underset{\hat{e}}{\operatorname{argmax}} \frac{w^{1-\gamma}-1}{1-\gamma}-c(\hat{e})+\beta\left[\hat{e} \mathbb{E}_{s z} V_{s^{\prime} z^{\prime}}^{h}+(1-\hat{e}) \mathbb{E}_{z} U_{z^{\prime}}^{h}\right]
$$

where the expected promised value next period

$$
\mathbb{E}_{s z} V_{s^{\prime} z^{\prime}}^{h}= \begin{cases}\mathbb{E}_{z} V_{1 z^{\prime}}^{h} & \text { if } s=1 \\ \mathbb{E}_{z}\left[\phi^{h} V_{1 z^{\prime}}^{h}+\left(1-\phi^{h}\right) V_{0 z^{\prime}}^{h}\right] & \text { if } s=0\end{cases}
$$

Here $\phi^{h}$ is the upgrading probability from a trainee to a skilled worker. Then the necessary and sufficient condition for $e$ to be the optimal effort is

$$
c^{\prime}(e)=\beta\left(\mathbb{E}_{s z} V_{s^{\prime} z^{\prime}}^{h}-\mathbb{E}_{z} U_{z^{\prime}}^{h}\right)
$$

Intuitively, effort is chosen to equate the marginal cost of effort with its marginal benefit. As effort cost function $c($.$) is increasing and strictly convex,$ $e$ increases with the expected promised value next period $\mathbb{E}_{s z} V_{s^{\prime} z^{\prime}}^{h}$ and is decreasing in the expected value of unemployment next period $\mathbb{E}_{z} U_{z^{\prime}}^{h}$.

I now describe the firm problem in terms of promised value. Consider the situation faced by a firm that is matched with a worker of skill type $s$ and education level $h$. Let $\Pi^{h}(s, z, V)$ be the expected discounted profit for the firm when the aggregate state is $z$ and the worker is offered with a continuation value $V$. If the match is separated, the firm is left with zero profit. Then $\Pi^{h}(s, z, V)$ must satisfy the following Bellman equation:

$$
\Pi^{h}(s, z, V)=\max _{w,\left\{V_{s^{\prime} z^{\prime}}^{h}\right\}, e} h z-\tau^{h}(1-s)-w+\beta e \mathbb{E}_{s z} \Pi^{h}\left(s^{\prime}, z^{\prime}, V_{s^{\prime} z^{\prime}}^{h}\right)
$$


where the expected profit next period

$\mathbb{E}_{s z} \Pi^{h}\left(s^{\prime}, z^{\prime}, V_{s^{\prime} z^{\prime}}^{h}\right)= \begin{cases}\mathbb{E}_{z} \Pi^{h}\left(1, z^{\prime}, V_{s^{\prime} z^{\prime}}^{h}\right) & \text { if } s=1 \\ \mathbb{E}_{z}\left[\phi^{h} \Pi^{h}\left(1, z^{\prime}, W_{1 z^{\prime}}\right)+\left(1-\phi^{h}\right) \Pi^{h}\left(0, z^{\prime}, W_{0 z^{\prime}}\right)\right] & \text { if } s=0\end{cases}$

subject to the promise-keeping constraint and the incentive-compatibility constraint

$$
\begin{aligned}
V & =\frac{w^{1-\gamma}-1}{1-\gamma}-c(e)+\beta\left[e \mathbb{E}_{s z} V_{s^{\prime} z^{\prime}}^{h}+(1-e) \mathbb{E}_{z} U_{z^{\prime}}^{h}\right] \\
c^{\prime}(e) & =\beta\left(\mathbb{E}_{s z} V_{s^{\prime} z^{\prime}}^{h}-\mathbb{E}_{z} U_{z^{\prime}}^{h}\right)
\end{aligned}
$$

The promise-keeping constraint (6) requires that the firm delivers the promised value $V$ to the worker. By increasing future promises, the firm can increase the effort level of its worker, and thus, increase the probability that the match continues. Note that promise-keeping and incentive-compatibility restrictions may define a set that is not convex. Then the profit function may not be concave. In this case, the solution to the dynamic programming problem above can be improved by using lotteries (Christopher Phelan and Robert M. Townsend, 1991). However, the optimal contract may not involve the use of lotteries, because convexity of the choice set is a sufficient but not necessary condition for concavity of the profit function. Indeed, in all my numerical computations, the profit function turns out to be concave, making lotteries redundant. Since the objective of this section is to derive some general properties of the optimal contracts, I will focus on the optimal program defined above, disregarding the use of lotteries.

\subsection{Search Markets and Equilibrium}

The meeting process between unemployed workers and vacancies is constrained by search frictions. The labour market is organized in a set of queues indexed by $(h, v)$, which are the required education level and the expected 
discounted value promised to workers in that given queue.

Each firm chooses in which queue they want to open a vacancy with a posting cost $\eta^{h}$, and each unemployed worker chooses where to queue. Each sub-market is characterized by its tightness represented by $\theta$, which is the ratio of the number of vacancies to the number of unemployed workers in this sub-market. The tightness captures the fact that a high ratio of vacancies to workers will make it harder for firms to hire. In a directed search model like the one presented here, the tightness is queue specific. I use a standard matching function that in queue $v$, a vacancy is filled with probability $q(\theta)=\theta^{\alpha-1}$, and a worker matches with probability $\mu(\theta)=\theta^{\alpha}$. Then

$$
\mu(\theta)=q(\theta)^{\frac{\alpha}{\alpha-1}}
$$

Here $0<\alpha<1$. In principle, different sub-markets could co-exist at the same time, but this does not happen in equilibrium. Anticipating such an outcome, the equilibrium definition specifies the labour market as a single tightness and promised value pair $\left(\theta_{z}^{h}, \mathbb{E}_{z} V_{0 z^{\prime}}^{h}\right)$ for each aggregate productivity $z$ and education level $h$. Appendix C.1 shows this result.

A competitive search equilibrium is defined along the lines of Moen (1997).

Definition 1. A competitive search equilibrium consists of: for each $(z, h)$, a value for unemployment $U_{z}^{h}$ and a sub-market with tightness $\theta_{z}^{h}$ and promised value $\mathbb{E}_{z} V_{0 z^{\prime}}^{h}$, such that

1. Search offers zero profit for a firm, i.e. the free entry condition equalizes the costs of posting a vacancy with the expected discounted profit

$$
\beta q\left(\theta_{z}^{h}\right) \cdot \mathbb{E}_{z} \Pi^{h}\left(0, z^{\prime}, V_{0 z^{\prime}}^{h}\right)-\eta^{h}=0
$$

where $\eta^{h}$ is the vacancy posting cost, and $q\left(\theta_{z}^{h}\right)$ is the probability of filling a vacancy. As the worker is initially untrained, $\mathbb{E}_{z} \Pi^{h}\left(0, z^{\prime}, V_{0 z^{\prime}}^{h}\right)$ is the firm's expected profit when matched with a trainee in the beginning of the match. 
(a) No Pareto improving sub-market is possible, i.e. there does not exist a sub-market $\left(\hat{\theta}_{z}^{h}, \mathbb{E}_{z} \hat{V}_{0 z^{\prime}}^{h}\right)$, s.t.

$$
\begin{aligned}
\mu\left(\hat{\theta}_{z}^{h}\right) \mathbb{E}_{z}\left(\hat{V}_{0 z^{\prime}}^{h}-U_{z^{\prime}}^{h}\right) & >\mu\left(\theta_{z}^{h}\right) \mathbb{E}_{z}\left(V_{0 z^{\prime}}^{h}-U_{z^{\prime}}^{h}\right) \\
\beta q\left(\hat{\theta}_{z}^{h}\right) \cdot \mathbb{E}_{z} \Pi^{h}\left(0, z^{\prime}, \hat{V}_{0 z^{\prime}}^{h}\right) & >\eta^{h}
\end{aligned}
$$

(b) The value for unemployment $U_{z}^{h}$ is consistent:

$$
U_{z}^{h}=\frac{\left(b^{h}\right)^{1-\gamma}-1}{1-\gamma}+\beta \mathbb{E}_{z}\left\{\mu\left(\theta_{z}^{h}\right) V_{0 z^{\prime}}^{h}+\left[1-\mu\left(\theta_{z}^{h}\right)\right] U_{z^{\prime}}^{h}\right\}
$$

\subsection{Contract Characterization}

I now proceed to derive some general properties of the optimal contract given that firms face the trade-off between insurance and incentives.

Lemma 1. The pareto frontier $\Pi^{h}(s, z, V)$ increases with the level of aggregate productivity $z$.

Proof. See Appendix C.2.

Proposition 1. Wages and expected firm profit have the following relationship

$$
w_{s^{\prime} z^{\prime}}^{\gamma}-w_{s z}^{\gamma}=\frac{\beta \mathbb{E}_{s z} \Pi^{h}\left(s^{\prime}, z^{\prime}, V_{s^{\prime} z^{\prime}}^{h}\right)}{e c^{\prime \prime}(e)}
$$

where $\mathbb{E}_{s z} \Pi^{h}\left(s^{\prime}, z^{\prime}, V_{s^{\prime} z^{\prime}}^{h}\right)$ is the expected firm profit next period, $w_{s z}$ is the current wage, and $w_{s^{\prime} z^{\prime}}$ is the wage next period.

Proof. See Appendix C.3.

The intuition behind Proposition 1 is that wage changes will have the same sign as expected firm profit. When $\mathbb{E}_{s z} \Pi^{h}\left(s^{\prime}, z^{\prime}, V_{s^{\prime} z^{\prime}}^{h}\right)=0$, the wage will not change $w_{s^{\prime} z^{\prime}}=w_{s z}$. Since effort cost function is strictly convex, i.e. 
$c^{\prime \prime}(e)>0$, when $\mathbb{E}_{s z} \Pi^{h}\left(s^{\prime}, z^{\prime}, V_{s^{\prime} z^{\prime}}^{h}\right)>0, w_{s^{\prime} z^{\prime}}^{\gamma}>w_{s z}^{\gamma}$, and thus, $w_{s^{\prime} z^{\prime}}>w_{s z}$ by concavity.

Lemma 1 and Proposition 1 provide a clear prediction for how wage changes are dependent on aggregate productivity. Whenever the firm expects positive (negative) profits due to aggregate productivity increases (decreases), it will be optimal to increase (decrease) the wage. This implies that wage changes track aggregate productivity shocks.

\subsection{Specific Capital, Effort Level and Wage Smoothing}

In this section, I show that the extent of wage smoothing is affected by the level of specific capital.

Lemma 2. The expected firm profit from hiring a trainee $\Pi^{h}(0, z, V)$ decreases with specific human capital.

Proof. See Appendix C.4.

From Lemma 2, more specific capital reduces a firm's incentive to post vacancies, leading to a decrease in the job finding rate in each sub-market, thereby reducing the value of a worker's outside options.

Proposition 2. The effort level of skilled workers increases with specific human capital.

Proof. See Appendix C.5.

The intuition behind Proposition 2 is that, in leaving their current jobs, skilled workers have to build up specific human capital again, so they have strong incentives to keep their jobs longer. These incentives increase with the level of specific capital, as more specific capital reduces the value of a worker's outside options in all aggregate states. Thus, skilled workers with more specific capital will make a greater effort to avoid job separation.

Proposition 3 needs the following sufficient condition: 
Assumption 3. The marginal cost of effort is convex. In other words, the second derivative of the effort cost function, $c^{\prime \prime}(e)$, increases with the level of effort.

Proposition 3. Given Assumption 3, wage smoothing of skilled workers increases with specific human capital.

Proof. The response of the effort level to increased incentives is

$$
\frac{d e}{d \beta \mathbb{E}_{z}\left(V_{1 z^{\prime}}^{h}-U_{z^{\prime}}^{h}\right)}=\frac{d\left(c^{\prime}\right)^{-1}\left[\beta \mathbb{E}_{z}\left(V_{z^{\prime}}-U_{z^{\prime}}\right)\right]}{d \beta \mathbb{E}_{z}\left(V_{1 z^{\prime}}^{h}-U_{z^{\prime}}^{h}\right)}=\frac{d e}{d c^{\prime}(e)}=\frac{1}{c^{\prime \prime}(e)}
$$

Then, we can rewrite the relationship between wage changes of skilled workers and the expected firm profit (Equation 13) as

$$
e \times\left(w_{1 z^{\prime}}^{\gamma}-w_{1 z}^{\gamma}\right)=\frac{d e}{d \beta \mathbb{E}_{z}\left(V_{1 z^{\prime}}^{h}-U_{z^{\prime}}^{h}\right)} \times \beta \mathbb{E}_{z} \Pi^{h}\left(1, z^{\prime}, V_{1 z^{\prime}}^{h}\right)
$$

The first term on the left-hand side of Equation (14) is the effort level, which equals the job continuation probability. From Proposition 2, skilled workers with more specific capital have higher levels of effort, and their jobs are less likely to break down, and thus, they will value more about firms' promises of future wage changes. As wage changes becomes more effective in motivating workers, firms do not need to give workers a lot of incentives. Intuitively, as skilled workers with more specific capital are less likely to leave their current jobs, firms do not have to increase wages to keep them in booms.

The first term on the right-hand side of Equation (14) is the response of $e$ to increased incentives. According to Assumption 3, as the level of effort increases, this response becomes smaller, and thus, it becomes increasingly costly for firms to provide incentives for worker effort. More specific capital increases the effort level of skilled workers, thereby increasing marginal cost of providing incentives for firms.

Firms face the trade-off between insurance and incentives. Given the same amount of expected profit, as more specific capital increases both the 
effectiveness and the marginal cost of providing incentives, it becomes optimal for firms to provide more insurance rather than more incentives, i.e. smaller wage changes caused by changes in aggregate productivity. Therefore, wage smoothing of skilled workers increases with the level of specific capital.

\section{Estimation}

To be able to use the model for quantifying the effect of specific capital on wage cyclicality, some of the model parameters are calibrated or fixed at externally estimated values, while others are directly estimated. I begin by describing fixed and externally estimated parameters and then turn to parameters estimated by the simulated method of moments.

\subsection{Fixed and Externally Estimated Parameters}

The parameter values that are fixed or externally estimated are listed in Table 7. A period in the model is 1 month. The discount factor is consistent with an annual real interest rate of $5 \%$. I normalize the amount of general skills for undergraduates $h_{B A}=1$. For the elasticity of the matching function, I draw from the evidence reported in Shimer (2005) and accordingly set $\alpha=0.28$. The probability of being upgraded from a trainee to a skilled worker $\phi$ is calculated as the inverse of the empirical adaptation duration in Table 4 using MCSUI. ${ }^{15}$

\footnotetext{
${ }^{15}$ Weeks are transformed to months by multiplying 4.33 , so that $\phi_{P G}=4.33 / 58.52=0.07, \quad \phi_{B A}=4.33 / 29.17=0.15, \quad \phi_{N C}=4.33 / 22.46=0.19$
} 
Table 7: Exogenous Parameter Values

\begin{tabular}{llcl}
\hline Description & Param. & Value & Source \\
\hline discount factor & $\beta$ & .996 & \\
general skill for BA & $h_{B A}$ & 1 & Normalization \\
matching function elasticity & $\alpha$ & .28 & Shimer (2005) \\
upgrading probability for a trainee & & \\
$\quad$ Postgraduates & $\phi_{P G}$ & .07 & MCSUI \\
\multicolumn{1}{l}{ Undergraduates } & $\phi_{B A}$ & .15 & MCSUI \\
\multicolumn{1}{l}{ Noncollege workers } & $\phi_{N C}$ & .19 & MCSUI \\
\hline
\end{tabular}

\subsection{Model Specification}

Given the parameters above, I estimate the model using the simulated method of moments and a parametrized model. I present the specification I use in this section. The aggregate productivity follows an $\operatorname{AR}(1)$ in logs, such that

$$
\ln z_{t}=\rho_{z} \ln z_{t-1}+v_{z t} \quad \text { where } v_{z t} \sim \mathcal{N}\left(0, \sigma_{z}^{2}\right)
$$

The worker effort function is

$$
c(e)=c_{0}\left[(1-e)^{-c_{1}}-1\right]
$$

such that $c(0)=0, \lim _{e \rightarrow 1} c(e)=\infty, c^{\prime}()>0,. c^{\prime \prime}()>0,. c^{\prime \prime \prime}()>.0 .{ }^{16} \mathrm{I}$ assume the vacancy posting cost and the flow value of unemployment are proportional to the amount of general skills to rule out different profitability (Pissarides, 2000)

$$
\begin{aligned}
\eta^{h} & =\eta * h \\
b^{h} & =b * h
\end{aligned}
$$

\footnotetext{
${ }^{16} c^{\prime}(e)=c_{0} c_{1}(1-e)^{-c_{1}-1}, c^{\prime}(0)=c_{0} c_{1}, \lim _{e \rightarrow 1} c^{\prime}(e)=\infty$. To deal with the corner solutions, I set effort to 0 if $c^{\prime}(0)<c_{0} c_{1}$, and effort can never be 1 as the cost is infinite.
} 
where $b$ can be interpreted as the unemployment insurance replacement rate. I relax these proportionality assumptions in Section D.2 and D.3.

These specifications leave me with the following 12 parameters to estimate:

$$
\left\{\rho_{z}, \sigma_{z}, \eta, b, c_{0}, c_{1}, \gamma, \tau_{P G}, \tau_{B A}, \tau_{N C}, h_{P G}, h_{N C}\right\}
$$

I perform my estimations using the simulated method of moments. The objective function is minimized over all parameters. The parameters of the aggregate productivity shock, $\rho_{z}$ and $\sigma_{z}$ are identified by the standard deviation and auto-correlation of $\log$ GDP. The amount of general skills $\left\{h_{P G}, h_{N C}\right\}$ are pinned down by the median postgraduate wage premium and the median undergraduate-noncollege wage premium. For the initial productivity gaps between trainees and skilled workers $\left\{\tau_{P G}, \tau_{B A}, \tau_{N C}\right\}$, I target the empirical data from DWS on percent losses in wages after job displacement in Table 5.

The vacancy cost $\eta$ affects the meeting rate through firm's free entry condition (9). The unemployment insurance replacement rate $b$ affects the value of unemployment, and thus, affects the probabilities of starting a job, since individuals without jobs will choose where to apply based on present value. Thus, job finding probabilities by education pin down $\eta$ and $b$. The parameters of the effort cost function $c_{0}$ and $c_{1}$ affect the average rate at which workers lose their jobs. They are pinned down by job separation rates by education. I construct these labour turnover rates from the monthly Current Population Survey 1979-2014. As GDP is only provided on a quarterly frequency, I take the quarterly average for all monthly series. Then, I log and HP filter the data with smoothing parameter $10^{5}$ to produce business cycle statistics. ${ }^{17}$

The parameter of risk aversion $\gamma$ controls how quickly changes in aggregate productivity are transmitted into wage changes. I target it at the elasticity of median wages with respect to GDP for undergraduates. Please note that the elasticity of median wages for postgraduates and noncollege

\footnotetext{
${ }^{17}$ The smoothing parameter is suggested by Shimer (2005).
} 
workers are not targeted. I leave them as model outcomes and show that the model is successfully able to match the non-targeted moments.

\subsection{Estimation Results}

Estimation is performed using the simulated method of moments. Since the model is strongly parametrized, I choose the weighting matrix to reflect how informative each moment should be about the parameters of interest. The default weight is chosen to be the inverse of the level to minimize a distance in relative deviation. The computation of standard errors is based on the pseudo-likelihood estimator presented in Chernozhukov and Hong (2003). Using Markov Chain Monte Carlo (MCMC) rejection sampling, I can perform the estimation without having to compute derivatives and still obtain standard errors on the parameters.

The parameter estimates are displayed in Table 8. The monthly aggregate productivity shock has a persistence of 0.985 . The standard deviation of the shock to the aggregate productivity is 0.0052 . The vacancy posting cost is 7.324. The unemployment insurance replacement rate is 0.557 . The level and the curvature of effort cost are 0.157 and 0.096 respectively. The risk aversion parameter is 1.116. The initial productivity gap for undergraduates is 0.173 , which is $35 \%$ of that for postgraduates. The initial productivity gap for noncollege workers is 0.137 . The amount of general human capital for noncollege workers is 0.682 and for postgraduates is 1.222.

The fitted moments in the data and their model simulations are shown in the columns "Data" and "Baseline" of Table 9. The model fits the moments quite well. One success of the model is that it can capture the turnover rates between postgraduates and undergraduates: undergraduates have higher probabilities both in job finding and job separation compared to postgraduates, and the relative differences are generally accurate. As the 
Table 8: Parameter Estimates

\begin{tabular}{lccc}
\hline Parameters & & Value & s.e. \\
\hline Persistence of aggregate productivity & $\rho_{z}$ & .985 & .0056 \\
Std. of shock to aggregate productivity & $\sigma_{z}$ & .0052 & .0019 \\
Vacancy posting cost & $\eta$ & 7.324 & 2.022 \\
Unemployment insurance replacement rate & $b$ & .557 & .077 \\
Level of effort cost & $c_{0}$ & .157 & .048 \\
Curvature of effort cost & $c_{1}$ & .096 & .024 \\
Risk aversion & $\gamma$ & 1.116 & .028 \\
Initial productivity gap & & & \\
$\quad \quad$ Postgraduate & $\tau_{P G}$ & .498 & .065 \\
$\quad$ Undergraduate & $\tau_{B A}$ & .173 & .051 \\
$\quad$ Noncollege & $\tau_{N C}$ & .137 & .053 \\
Formal human capital & & & \\
$\quad$ Postgraduate & $h_{P G}$ & 1.222 & .041 \\
$\quad$ Noncollege & $h_{N C}$ & .682 & .061 \\
\hline
\end{tabular}

The computation of standard errors is based on the pseudo-likelihood estimator presented in Chernozhukov and Hong (2003).

job separation rate equals 1 minus the average level of effort, postgraduates maintain a higher level of effort in their current job than undergraduates do. The job separation rate for noncollege workers is lower than its counterpart in the US. This is because, in this model, job separation is only a result of lack of worker effort. On the one hand, this suggests that the estimation might benefit from making the parameters for the effort cost function heterogeneous across education levels. On the other hand, there are many other factors that might lead to higher job separation for this group, and thus, imposing an exogenous job separation rate would move the fit in the right direction. 
Table 9: Model Fit

\begin{tabular}{lrr}
\hline Moments & Data & Baseline \\
\hline Postgraduates & & \\
$\quad$ Job separation rate & .005 & .005 \\
Job finding rate & .245 & .248 \\
$\quad$ Percent wage losses after displacement & -.178 & -.176 \\
\hline Undergraduates & & \\
$\quad$ Job separation rate & .007 & .009 \\
Job finding rate & .263 & .263 \\
Percent wage losses after displacement & -.086 & -.089 \\
$\quad$ Elasticity of median wage to GDP & .58 & .58 \\
\hline Noncollege workers & & \\
$\quad$ Job separation rate & .016 & .009 \\
Job finding rate & .272 & .265 \\
$\quad$ Percent wage losses after displacement & -.086 & -.086 \\
\hline Common moments & & \\
$\quad$ Median postgraduate wage premium & 1.23 & 1.219 \\
Median undergraduate wage premium & 1.47 & 1.466 \\
std $[G D P]$ & .024 & .024 \\
autocorr $[G D P]$ & .954 & .955 \\
\hline
\end{tabular}

\section{Analysis}

\subsection{Cyclical Properties of Wages and Wage Premium}

Table 10 shows the cyclicality of wages and wage premium in the data and their model simulations. Please note only the wage cyclicality for undergraduates is targeted in the estimation; the wage cyclicalities for postgraduates and noncollege workers are not targeted.

Overall, the model correctly captures the cyclicality of wages and wage premium: The undergraduate wage is more pro-cyclical than the postgraduate wage, and is about the same as the noncollege wage. The postgraduate 
Table 10: Cyclicality of Wages and Wage Premium

\begin{tabular}{lccc}
\hline Moments & Type & Data & Baseline \\
\hline Elasticity of median wage to GDP & Non-targeted & .34 & .322 \\
$\quad$ Postgraduates & Targeted & .58 & .58 \\
$\quad$ Undergraduates & Non-targeted & .57 & .574 \\
$\quad$ Noncollege workers & & & \\
Elasticity of median wage premium to GDP & & \\
$\quad$ Postgraduate wage premium $\left(w_{P G} / w_{B A}\right)$ & Non-targeted & -.24 & -.258 \\
$\quad$ Undergrad. wage premium $\left(w_{B A} / w_{N C}\right)$ & Non-targeted & .01 & .006 \\
\hline
\end{tabular}

Notes: Non-targeted moments are not targeted in the estimation.

wage premium is counter-cyclical; the undergraduate wage premium is acyclical. The elasticity of median postgraduate wage premium to GDP is -0.258 , and the elasticity of undergraduate wage premium is 0.006 , which are about the same size as the data.

Figure 2 plots the GDP and wages simulated from the model. The dotted line is the GDP, the solid line is the postgraduate wage, and the dashed line is the undergraduate wage. As each series is logged and demeaned, it shows the percentage deviation from the mean. It shows that both the postgraduate wage and the undergraduate wage are pro-cyclical, but the postgraduate wage fluctuates less than the undergraduate wage. Therefore, the model picks up the fact that the postgraduate wage is smoother than the undergraduate wage over the business cycle. ${ }^{18}$

\subsection{Effect of Specific Capital on Wage Cyclicality}

To examine the importance of specific capital on wage cyclicality, I run a counterfactual simulation where postgraduates have the same low level of specific capital as undergraduates: upgrade probability $\phi$ is increased from

\footnotetext{
${ }^{18}$ Appendix D evaluates the plausibility of other potential explanations for the countercyclical postgraduate wage premium.
} 


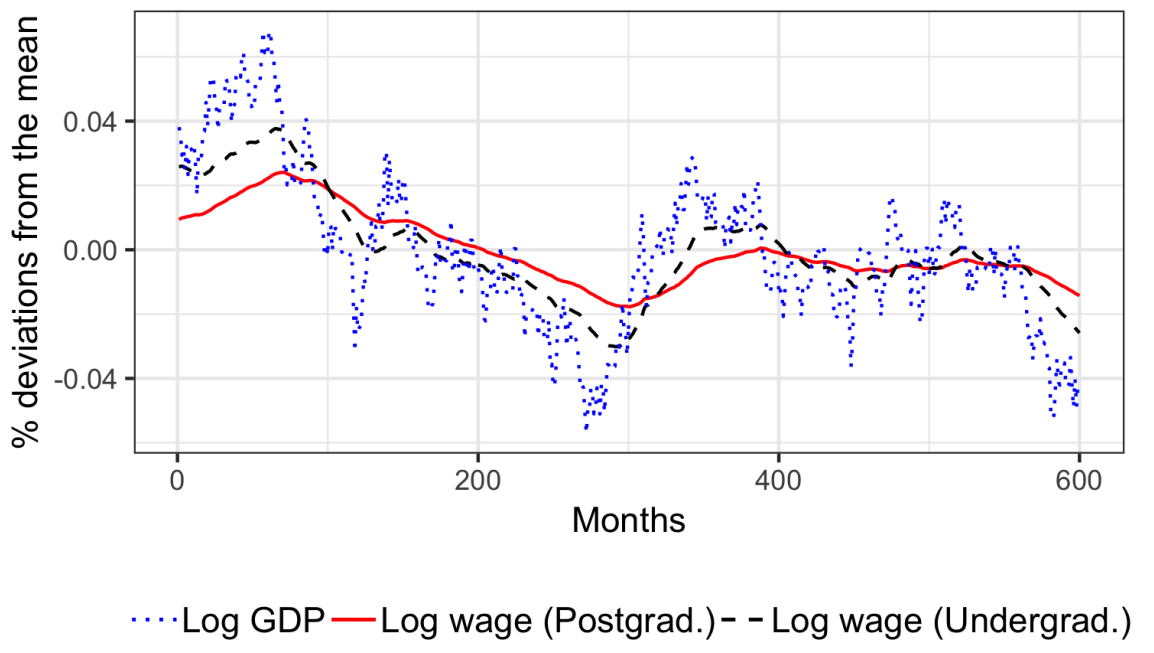

Figure 2: Demeaned Log GDP and Log Wages by Education

0.07 to 0.15 , and the initial productivity gap $\tau$ is reduced from 0.498 to 0.173 . I report the simulation results in the column "Low Capital" of Table 11.

The first row of column "Low Capital" shows that when postgraduates have lower specific capital, the job separation rate increases to 0.01 from 0.005 in the baseline. As there is less to lose if they move to a new job, they make a lower level of effort to keep their jobs. A decrease in the average duration of job adaptation and the initial productivity gap increase the value of a new job. Consequently, firms have a greater incentive to post vacancies. In the second row of "Low Capital", the job finding rate of the postgraduates increases to 0.265 from 0.248 in the baseline. Hence, when holding the same level of specific capital, postgraduates and undergraduates have the same level of labour market turnover rates.

The most important changes are to wage cyclicality. The 4th row of "Low Capital" shows that when postgraduates have lower costs, the wage elasticity to GDP increases $86 \%$ from 0.322 to 0.599 , indicating that the 
Table 11: Low Level of Specific Capital for Postgraduates

\begin{tabular}{lcc}
\hline Moments & Baseline & Low Capital \\
\hline Postgraduates & & \\
Job separation rate & .005 & .010 \\
Job finding rate & .248 & .265 \\
Percent wage losses after displacement & -.176 & -.083 \\
$\quad$ Elasticity of median wage to GDP & .322 & .599 \\
\hline Undergraduates & & \\
$\quad$ Job separation rate & .009 & .009 \\
Job finding rate & .263 & .263 \\
Percent wage losses after displacement & -.089 & -.089 \\
$\quad$ Elasticity of median wage to GDP & .58 & .58 \\
\hline Postgraduate wage premium $\left(w_{P G} / w_{B A}\right)$ & & \\
$\quad$ Median & 1.219 & 1.222 \\
$\quad$ Elasticity to GDP & -.258 & .018
\end{tabular}

Baseline: baseline calibration; Low Capital: Postgraduates have the same low level of specific capital as undergraduates.

postgraduate wage fluctuates more over the business cycle and is as cyclical as the undergraduate wage. In the last row of "Low Capital", the elasticity of postgraduate wage premium to GDP changes from -0.258 to 0.018 , i.e. the postgraduate wage premium changes from counter-cyclical to acyclical. So once holding the level of specific capital equal, the model generates same wage cyclicality across education groups. This result shows that specific capital explains the difference in the wage cyclicality between postgraduates and undergraduates.

Figure 3 compares log median wages with different levels of specific capital. The solid line is the log median wage of postgraduates in the baseline simulation, the dashed line is the log median wage of postgraduates in the "Low Capital" simulation, and the dotted line is the log median wage of undergraduates in the baseline. First, in comparing educations levels, postgraduate wages are higher than undergraduate wages. When I compare within postgraduate wages, the postgraduate wage in the baseline is smoother than 
that in the "Low Capital" simulation, which is also the result of Proposition 3. The postgraduate wage in the "Low Capital" simulation fluctuates as much as the undergraduate wage in the baseline. Interestingly, in Figure 3 , the postgraduate wage in the "Low Capital" simulation is higher than that in the baseline simulation. Thus, a low level of specific capital shifts the postgraduate wage up. In the penultimate row of column "Low Capital" of Table 9, the postgraduate wage premium increases to 1.222 from 1.219 in the baseline. There, when I hold the level of specific capital equal, the postgraduate wage premium increases. As postgraduates have more specific capital than undergraduates, they accept relatively low wages, leading to a smaller wage premium.

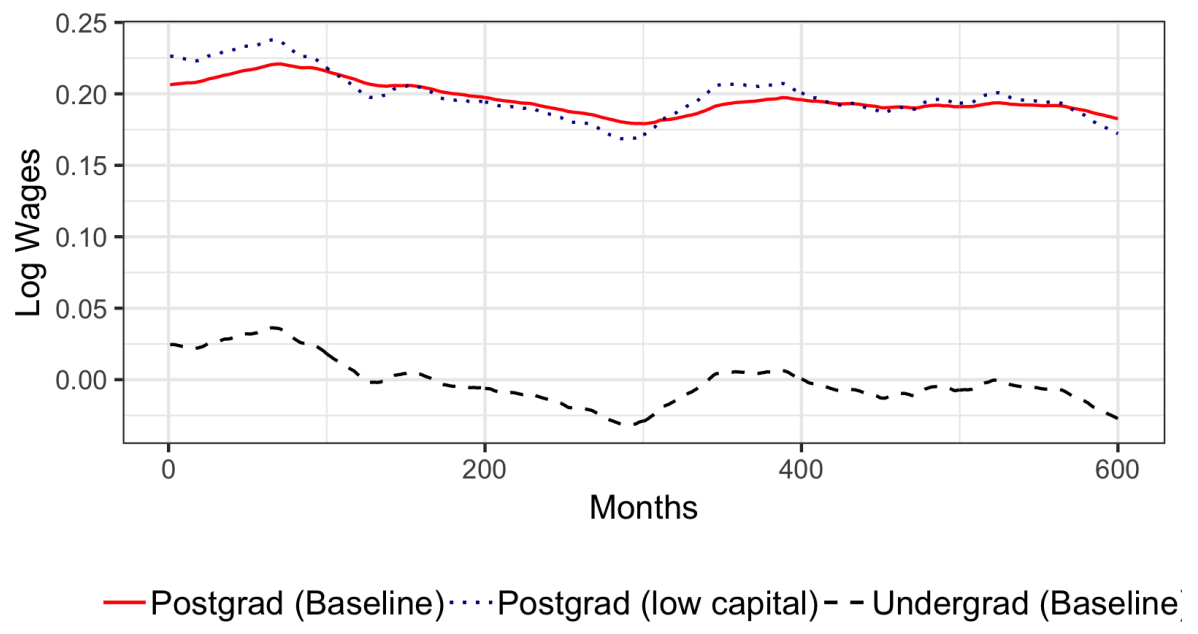

Figure 3: Effect of Specific Capital on Wage Cyclicality

Figure 5 in Appendix C.6 plots the wage-tenure profiles by education. It shows that the gap between the starting wage of postgraduates and their average wage is greater than that of undergraduates, but the subsequent wage growth of postgraduates is faster. This result extends the specific human 
capital hypothesis in Chapman and Tan (1980) - that the starting wage and the rate of wage growth are negatively related - to the context of education wage gaps.

\section{Policy Evaluation}

In this section, I use the model to test whether the wage insurance provided by firms against aggregate shocks (firm insurance) will be crowded out by social insurance. I evaluate a more generous unemployment insurance policy - the unemployment insurance replacement rate is increased by $20 \%$. Such policy provides better social insurance when workers are unemployed, which raises the value of worker's outside options. Then, workers are more likely to shirk their effort, and thus, firms have a greater incentive to adjust wages.

I report the simulation results in the column "High UI" of Table 12. First, understanding that the government is providing more insurance, firms choose to pass on more of the aggregate shocks to their workers. The result is an increase in the wage cyclicality: the wage elasticity to GDP increases by $12 \%$ for postgraduates, $10 \%$ for undergraduates, and $9 \%$ for noncollege workers. Thus, unemployment insurance crowds out firm insurance, but to a less extent for lower-educated workers.

In Table 12, I also compute the worker's willingness to pay for such a policy for each education group. To define the willingness to pay, I write the lifetime expected utility of an individual as

$$
\mathbb{E} U_{d}=\mathbb{E} \sum_{t=0}^{\infty} \beta^{t}\left[\frac{w_{d t}^{1-\gamma}-1}{1-\gamma}-c\left(e_{d t}\right)\right]
$$

where the subscript $d$ refers to the baseline economy $(d=1)$ or an alternative more generous economy $(d=2)$. Now define $\pi$ as the proportion of 
Table 12: Raise UI replacement rate

\begin{tabular}{lccc}
\hline Moments & Baseline & High UI & \% change \\
\hline Postgraduates & & & \\
$\quad$ Median wage & 1.22 & 1.22 & $0 \%$ \\
$\quad$ Elasticity of median wage to GDP & .322 & .36 & $12 \%$ \\
$\quad$ Willingness to pay $\pi$ & & $.42 \%$ & \\
\hline Undergraduates & 1 & 1 & $0 \%$ \\
$\quad$ Median wage & .58 & .638 & $10 \%$ \\
$\quad$ Elasticity of median wage to GDP & $.72 \%$ & \\
$\quad$ Willingness to pay $\pi$ & & & \\
\hline Noncollege workers & .68 & .68 & $0 \%$ \\
$\quad$ Median wage & .623 & $9 \%$ \\
$\quad$ Elasticity of median wage to GDP & .574 & $.74 \%$ & \\
$\quad$ Willingness to pay $\pi$ & & \\
\hline
\end{tabular}

Baseline: baseline calibration; High UI: $20 \%$ increase in the unemployment insurance replacement rate; "\% change": percentage change in values between "High UI" and "Baseline".

consumption an individual is willing to pay to be indifferent between environment $d=2$ and $d=1$. This is implicitly defined by

$$
\begin{aligned}
& \mathbb{E} U_{1}=\left.\mathbb{E} U_{2}\right|_{\pi} \equiv \mathbb{E} \sum_{t=0}^{\infty} \beta^{t}\left\{\frac{\left((1-\pi) w_{2 t}\right)^{1-\gamma}-1}{1-\gamma}-c\left(e_{2 t}\right)\right\} \\
& \pi=1-\left[\frac{\mathbb{E}_{0} U_{1}+A+B}{\mathbb{E}_{0} U_{2}+A+B}\right]^{\frac{1}{1-\gamma}}
\end{aligned}
$$

where $A=\frac{1}{(1-\gamma)(1-\beta)}$ and $B=\mathbb{E} \sum_{t=0}^{\infty} \beta^{t} c\left(e_{2 t}\right)$.

For a $20 \%$ increase in the UI replacement rate, postgraduates are willing to pay $0.4 \%$ of their consumption, whereas undergraduates and noncollege workers are willing to pay $0.7 \%$ of their consumption. Hence, lower-educated workers have a higher welfare gain than postgraduates from such a policy, which supports the argument for a regressive UI replacement rate schedule, i.e. that the unemployment insurance replacement rate should be lower for postgraduates. 


\section{Conclusion}

I document a new result: in the US, the postgraduate wage premium is counter-cyclical - postgraduates have smaller cyclical wage variation than undergraduates. I further document that the difference in wage cyclicality between postgraduates and undergraduates is significant for workers with a long job tenure, but not for new hires. As workers' job tenure is the generally used proxy for specific human capital, I argue that this phenomenon occurs because postgraduates accumulate more specific capital than undergraduates. I provide robust empirical evidence that is consistent with the theory: 1) Postgraduates need more time to adapt to new jobs than undergraduates; 2) Postgraduates suffer larger wage losses from job displacement.

To understand how specific capital affects labour turnover and wage cyclicality, I develop an equilibrium search model with long-term contracts and imperfect monitoring of worker effort. Imperfect monitoring creates a moral hazard problem that requires firms to pay efficiency wages. The theoretical implication of the model is that more specific capital leads to lower mobility, thereby increasing both the effectiveness and the marginal cost of providing incentives for worker effort. As firms face the trade-off between insurance and incentives, it is optimal for them to provide more insurance rather than more incentives. Therefore, more specific capital leads to smoother wages.

I quantify the level of specific human capital by education in the data and use it to parameterize my model. The model captures differences in wage cyclicality and labour turnover between education groups, indicating that specific capital is an important driving force. The paper implies that lower educated workers, and even undergraduates, are unlikely to receive

much insurance from firms, hence increasing the demand for social insurance among this group. I analyze the impact of an increase in the unemployment insurance replacement rate. I find such a policy crowds out wage insurance provided by firms, but the effect is smaller for lower educated workers. Lower educated workers have a higher welfare gain from such a policy than post- 
graduates, which supports the argument for a lower UI replacement rate for postgraduates.

\section{References}

Altonji, Joseph G., and Nicolas Williams. 2005. "Do wages rise with job seniority? A reassessment." Industrial and Labor Relations Review, $58(3)$.

Altonji, Joseph G., and Robert A. Shakotko. 1987. "Do Wages Rise with Job Seniority?" Review of Economic Studies, 54(3): 437-459.

Azariadis, Costas. 1975. "Implicit Contracts and Underemployment Equilibria." Journal of Political Economy, 83(6): 1183-1202.

Azariadis, Costas. 1976. "On the Incidence of Unemployment." Review of Economic Studies, 43(1): 115-125.

Beaudry, Paul, and John DiNardo. 1991. "The Effect of Implicit Contracts on the Movement of Wages Over the Business Cycle: Evidence from Micro Data." Journal of Political Economy, 99(4): 665-688.

Becker, Gary. 1962. "Investment in Human Capital : A Theoretical Analysis." Journal of Political Economy, 70(5): 9-49.

Blundell, Richard, Luigi Pistaferri, and Ian Preston. 2008. "Consumption inequality and partial insurance." American Economic Review, 98(5): 1887-1921.

Burdett, Kenneth, and Melvyn G. Coles. 2003. "Equilibrium WageTenure Contracts." Econometrica, 71(5): 1377-1404.

Cairó, Isabel, and Tomaz Cajner. 2016. "Human capital and unemployment dynamics: why more-educated workers enjoy greater employment stability." The Economic Journal, 44: 1-40. 
Chapman, Bruce J, and Hong W. Tan. 1980. "Specific Training and Inter-Industry Wage Differentials in U. S. Manufacturing." The Review of Economics and Statistics, 62(3): 371-378.

Chernozhukov, Victor, and Han Hong. 2003. "An MCMC approach to classical estimation." Journal of Econometrics, 115(2): 293-346.

Christopher Phelan, and Robert M. Townsend. 1991. "Computing Multi-Period, Information-Constrained Optima." Review of Economic Studies, 58(5): 853-881.

Dustmann, Christian, and Costas Meghir. 2005. "Wages, Experience and Seniority." Review of Economic Studies, 72: 77-108.

Flood, Sarah, Miriam King, Renae Rodgers, Steven Ruggles, and J. Robert Warren. 2018. "Integrated Public Use Microdata Series, Current Population Survey: Version 6.0 [dataset]." Minneapolis, MN: IPUMS.

Hashimoto, Masanori. 1975. "Wage Reduction, Job Separation and Specific Human Capital." Economic Inquiry, 13(4): 485-504.

Heathcote, Jonathan, Kjetil Storesletten, and Giovanni L Violante. 2005. "Two Views of Inequality over the Life Cycle." Journal of the European Economic Association, 3(2/3, Papers and Proceedings of the Nineteenth Annual Congress of the European Economic Association): 765-775.

Heckman, J J. 1979. "Sample Selection Bias as a Specification Error." Econometrica, 47(1): 153-161.

Hudomiet, Péter. 2015. "The role of occupation specific adaptation costs in explaining the educational gap in unemployment." Working Paper.

Keane, Michael P, and Eswar Prasad. 1993. "Skill Levels and the Cyclical Variability of Employment, Hours, and Wages." Staff Papers (International Monetary Fund), 40(4): 711-743. 
Krueger, Dirk, and Fabrizio Perri. 2005. "Understanding Consumption Smoothing: Evidence from The U.S. Consumer Expenditure Data." Journal of the European Economic Association, 3(2/3, Papers and Proceedings of the Nineteenth Annual Co): 340-349.

Krueger, Dirk, and Fabrizio Perri. 2006. "Does Income Inequality Lead to Consumption Inequality? Evidence and Theory." The Review of Economic Studies, 73(1): 163-193.

Lamadon, Thibaut. 2016. "Productivity Shocks, Dynamic Contracts and Income Uncertainty." Working Paper.

Lindley, Joanne, and Stephen Machin. 2016. "The Rising Postgraduate Wage Premium." Economica, 83(330): 281-306.

Lindquist, Matthew J. 2004. "Capital-skill complementarity and inequality over the business cycle." Review of Economic Dynamics, 7(3): 519-540.

Menzio, Guido, and Shouyong Shi. 2011. "Efficient Search on the Job and the Business Cycle." Journal of Political Economy, 119(3): 468-510.

Moen, Espen R. 1997. "Competitive Search Equilibrium." Journal of Political Economy, 105(2): 385-411.

Mortensen, Dale T., and Christopher A. Pissarides. 1994. "Job Creation and Job Destruction in the Theory of Unemployment." Review of Economic Studies, 61(3): 397-415.

Pissarides, Christopher A. 2000. Equilibrium unemployment theory.

Raisian, John. 1979. "Cyclic Patterns in Weeks and Wages." Economic Inquiry, 17(4): 475.

Robin, Jean-Marc. 2011. "On the Dynamics of Unemployment and Wage Distributions." Econometrica, 79(5): 1327-1355. 
Rudanko, Leena. 2009. "Labor market dynamics under long-term wage contracting." Journal of Monetary Economics, 56(2): 170-183.

Shimer, Robert. 2005. "The cyclical behavior of equilibrium unemployment and vacancies." Annual Review of Economics, 95(1): 25-49.

Shimer, Robert. 2012. "Reassessing the ins and outs of unemployment." Review of Economic Dynamics, 15(2): 127-148.

Spear, Stephen E., and Sanjay Srivastava. 1987. "On Repeated Moral Hazard with Discounting." Review of Economic Studies, 54(4): 599.

Swanson, Eric T. 2007. "Real Wage Cyclicality in the Panel Study of Income Dynamics." Scottish Journal of Political Economy, 54(5).

Topel, Robert. 1991. "Specific Capital, Mobility, and Wages: Wages Rise with Job Seniority." Journal of Political Economy, 99(1): 145-176.

Tsuyuhara, Kunio. 2016. "Dynamic contracts with worker mobility via directed on-the-job search." International Economic Review, 57(4): 14051424. 


\section{A Additional Details on Data}

\section{A.1 Current Population Survey (CPS)}

The CPS is designed to be representative of the civilian non-institutional population. The survey interviews about 60,000 households at a monthly frequency on a short rotating basis. I merge monthly CPS data to create a short panel. Specifically, I use the code by Robert Shimer ${ }^{19}$, combined with monthly CPS files downloaded from NBER ${ }^{20}$. See Shimer (2012) for a further discussion of the issues involved in linking individuals across months in the monthly CPS files. The short panel allows me to estimate job separation rate and job finding rate from 1979-2014. Since the introduction of dependent interviewing techniques with the 1994 redesign of the CPS, the survey asks whether an employed worker works for the same employer as last month. I use this fact to estimate the job-to-job transition rate from 1994-2014. I use the provided monthly CPS weight.

In addition to the monthly CPS, in march every year the CPS fields the Annual Social and Economic supplement (March CPS), which collects detailed demographic data for each household member and labor force and income information for each household member age 15 or older. I download the March CPS data from https://cps.ipums.org/cps/, which are available at the state level starting in 1976. Labor force and income information correspond to the previous year. I use the March supplement weights to produce my estimates on wage cyclicality.

The Displaced Workers Survey (DWS) is another supplement to the CPS administered in the January or February of every even year. The DWS identifies displaced workers who have been separated from their employers due to (i) insufficient demand for the worker's services, (ii) the worker's position being abolished, or (iii) the worker's plant closing — reasons which

\footnotetext{
${ }^{19}$ https://sites.google.com/site/robertshimer/research/flows

${ }^{20}$ http://www.nber.org/data/cps_basic.html
} 
have been taken by the literature to instrument for "exogenous" layoffs. The DWS inherits the large sample size and representative structure of the CPS and also records information on earnings on both the displaced and current job.

\section{A.2 Panel Study of Income Dynamics (PSID)}

The PSID is a longitudinal study of US households and individuals. The original 1968 sample was drawn from two independent sub-samples: an oversample of roughly 2000 poor families selected from the Survey of Economic Opportunities (SEO), and a nationally representative sample of roughly 3000 families designed by the Survey Research Center (SRC) at the University of Michigan. In 1997, the SEO sample was reduced by one-half. In 1990, PSID added 2000 Latino households, including families originally from Mexico, Puerto Rico, and Cuba. While this sample (the so-called "Latino sample") did represent three major groups of immigrants, it missed out on the full range of post-1968 immigrants, Asians in particular. Because of this crucial shortcoming, and a lack of sufficient funding, the Latino sample was dropped after 1995. A sample of 441 immigrant families, including Asians, was added in 1997 (the so-called "Immigrant sample").

Since 1968, the PSID has interviewed individuals from families in the initial samples. Adults have been followed as they have grown older, and children have been observed as they have advanced into adulthood, forming family units of their own (the "split-offs"). Survey waves are annual from 1968 to 1997, and biennial since then. Although the PSID provides a wide variety of information about all individuals in the family unit, the greatest level of detail is ascertained for the primary adult in the family unit, i.e., the head ${ }^{21}$. In the PSID all the questions are retrospective, i.e., variables in

\footnotetext{
${ }^{21}$ The head of the family unit (FU) must be at least 16 years old, and the person with the most financial responsibility in the FU. If this person is female and she has a husband in the $\mathrm{FU}$, then he is designated as head. If she has a boyfriend with whom she has been living for at least one year, then he is head. However, if she has 1) a husband or a boyfriend
} 
survey-year t refer to calendar year $t-1$. The interview is usually conducted around March.

I base my empirical analysis on the SRC sample. I use all the yearly surveys from 1985-1996 and the biennial surveys from 1997-2015. I start in 1985 because the variable on highest degree received is available only since $1985^{22}$. I restrict the sample to male heads aged 26 to 64 who were not selfemployed, and I only use the first spell I observe someone as a head. Wages are annual hourly wages (annual labour earnings divided by annual hours). Nominal wages are deflated by the Consumer Price Index. The base year is 2000. I also restrict the sample to hourly wage less than or equal to $\$ 100$. Workers who worked less than 520 hours per year or whose hourly wage rate was below $\$ 1$ (in 2000 dollars) or less than half of the corresponding federal minimum wage in that year are viewed as non-employed. I create consistent measure of age: I determine the age in the first year the respondent was a head, and then increment age by 1 for each subsequent year the respondent was a head.

\section{A.3 Multi-City Study of Urban Inequalities (MCSUI)}

The MCSUI was collected in four large US cities (Los Angeles, Boston, Detroit and Atlanta) between 1992 and 1994. It aims to understand why high rates of joblessness have persisted among minorities living in America's central cities. One important aspect of the study was the contacting of more than 3000 employers to ask detailed questions about their hiring practices.

who is incapacitated and unable to fulfill the functions of head, 2) a boyfriend who has been living in the FU for less than a year, 3) no husband/boyfriend, then the FU will have a female head. A new head is selected if last year's head moved out of the household unit, died or became incapacitated, or if a single female head has gotten married. Also, if the family is a split-off family (hence a new family unit in the sample), then a new head is chosen.

${ }^{22}$ Although individual's years of education is available before 1985, almost no one has more than 16 years of education before 1983 in my sample, which is not useful for the analysis of postgraduates. 
Even though the intent of the study was to understand racial discrimination in hiring, the exhaustive information about the recruitment process makes this study valuable for broader purposes. The sampling procedure and the provided weights intend to represent employees who worked in the 4 cities in 1992. A subsection of the survey asked employers about their most recently hired worker. One of the questions is "How many weeks does it take the typical employee in this position to become fully competent in it?" I use it to analyze the adaptation duration by education in this paper.

\section{B Additional Details on Empirical Facts}

\section{B.1 Robustness Check of Regression (1)}

\section{GDP as an Indicator of the Business Cycle}

Instead of the unemployment rate, I use log real GDP as an indicator of the business cycle and run the following regression

$$
\ln W_{i t}=\theta P G_{i t}+\alpha \ln \mathrm{GDP}_{t}+\gamma P G_{i t} \times \ln \mathrm{GDP}_{t}+X_{i t} \beta+\varepsilon_{i t}
$$

$\alpha$ indicates the relation between the undergraduate wage and GDP. For instance, a positive estimate of $\alpha$ would imply that the average real wage of undergraduates increases when GDP rises, i.e. the undergraduate wage is pro-cyclical. The coefficients $\gamma$ captures the difference between the cyclicality of the postgraduate wage and the undergraduate wage, and $\alpha+\gamma$ indicates the cyclicality of the postgraduate wage. A negative estimate of $\gamma$ would indicate a counter-cyclical postgraduate wage premium - the premium decreases when GDP rises. The estimates are in column (1) of Table 13. It shows that when real GDP increases by $1 \%$, the postgraduate wage increases by $0.403 \%$ and the undergraduate wage increases by $0.988 \%$, confirming the finding that the postgraduate wage is less pro-cyclical than the 
undergraduate wage.

\section{Cubic Detrending, Median Regression, and Age Groups}

In column (2) of Table 13, I detrend the aggregate unemployment rate using a cubic time trend and find that when the unemployment rate goes up by 1 percentage point, postgraduates face a $0.64 \%$ increase in their real wage relative to that of undergraduates. In column (3), I run a median regression and find that when the unemployment rate goes up by 1 percentage point, the median wage of postgraduates increases by $0.74 \%$ relative to that of undergraduates. In column (4) and (5), I cut the baseline sample into 2 age groups. I find that when the unemployment rate goes up by 1 percentage point, postgraduates aged $26-40$ face a $0.86 \%$ wage increase relative to undergraduates in the same age group, and postgraduates aged 41-64 face a $0.70 \%$ relative wage increase. So having a postgraduate degree significantly reduces wage cyclicality for both age groups.

\section{Job Stayers and Heckman Selection Model}

A typical selection bias problem is that undergraduates are more likely to be unemployed than postgraduates in recessions, so the average undergraduate wage increases mechanically relative to the average postgraduate wage. To eliminate such systematic selection, I run the regression (1) with only job stayers - workers who stayed in the same job last year, had no stretch of looking for work, and worked for 52 weeks. Column (6) of Table 13 shows that the coefficient $\gamma$ on $P G_{i t} \times U_{t}$ shrinks slightly to 0.0069 (s.e. 0.0022 ). Therefore, job separation can only explain a small amount of the countercyclical postgraduate premium.

Besides, I use a maximum likelihood version of Heckman (1979) selection model. This model estimates a wage equation jointly with probit choice equation that determines whether a worker is employed. The model is written as follows: 
Table 13: Robustness - Regression of Real Hourly Wage on Degree Interaction

\begin{tabular}{|c|c|c|c|}
\hline lnWage & $\begin{array}{l}(1) \\
\ln \mathrm{GDP}\end{array}$ & & \\
\hline $\ln G D P(\alpha)$ & $\begin{array}{c}.988 \\
(.074)\end{array}$ & & \\
\hline$P G \times \ln G D P(\gamma)$ & $\begin{array}{l}-.584 \\
(.119)\end{array}$ & & \\
\hline$\alpha+\gamma$ & $\begin{array}{l}.403 \\
(.094) \\
\end{array}$ & & \\
\hline & $(2)$ & $(3)$ & $(4)$ \\
\hline lnWage & Cubic Detrend & Median & $26^{\sim} 40$ \\
\hline$U R A T E(\alpha)$ & $\begin{array}{l}-.0105 \\
(.0011)\end{array}$ & $\begin{array}{l}-.0099 \\
(.0013)\end{array}$ & $\begin{array}{l}-.0157 \\
(.0016)\end{array}$ \\
\hline$P G \times U R A T E(\gamma)$ & $\begin{array}{c}.0064 \\
(.0017)\end{array}$ & $\begin{array}{c}.0074 \\
(.0021)\end{array}$ & $\begin{array}{c}.0086 \\
(.0029)\end{array}$ \\
\hline$\alpha+\gamma$ & $\begin{array}{l}-.0041 \\
(.0014)\end{array}$ & $\begin{array}{l}-.0026 \\
(.0017)\end{array}$ & $\begin{array}{l}-.0071 \\
(.0024)\end{array}$ \\
\hline & $(5)$ & $(6)$ & $(7)$ \\
\hline lnWage & $41^{\sim} 64$ & Job Stayers & Heckman \\
\hline$U R A T E(\alpha)$ & $\begin{array}{l}-.0094 \\
(0019)\end{array}$ & $\begin{array}{l}-.0106 \\
(.0013)\end{array}$ & $\begin{array}{l}-.0121 \\
(.0012)\end{array}$ \\
\hline$P G \times U R A T E(\gamma)$ & $\begin{array}{c}.0070 \\
(.0029)\end{array}$ & $\begin{array}{c}.0069 \\
(.0022)\end{array}$ & $\begin{array}{c}.0084 \\
(.0021)\end{array}$ \\
\hline$\alpha+\gamma$ & $\begin{array}{l}-.0023 \\
(.0023)\end{array}$ & $\begin{array}{l}-.0037 \\
(.0018)\end{array}$ & $\begin{array}{l}-.0037 \\
(.0017)\end{array}$ \\
\hline
\end{tabular}

(1) Use Log real GDP as an indicator of the business cycle; (2) Unemployment rate is detrended by a cubic trend; (3) Median regression; (4) Aged 26 40; (5) Aged 41 64; (6) Workers had only 1 employer, no stretch of looking for work, and worked for 52 weeks; (7) Heckman selection model with first-stage employment choice. Controls: postgraduate degree, state, race, and marriage dummies, a cubic age trend and a quartic time trend. 


$$
\begin{aligned}
& \ln W_{i t}= \theta P G_{i t}+\alpha U_{t}+\gamma P G_{i t} \times U_{t}+X_{i t} \beta+\varepsilon_{i t}, \\
& \text { where } \quad P_{i t}^{*}= \delta P G_{i t}+\delta U_{t}+\eta P G_{i t} \times U_{t}+Z_{i t} \beta_{0}+\omega_{i t}, \\
& P_{i t}= \begin{cases}1 & \text { if } P_{i t}^{*} \geq 0 \\
0 & \text { if } P_{i t}^{*}<0\end{cases}
\end{aligned}
$$

Here $P_{i t}^{*}$ is the latent index of a probit employment equation that determines whether worker $i$ is employed at time $t$. $Z_{i t}$ is a vector of individual-specific regressors that affect the probability of employment. Typically, it contains elements that enter into $X_{i t}$ as well as some additional variables that may affect labour supply propensity but not worker productivity. The additional variables are: number of own children in the household, number of own children under age 5 in the household, and age of youngest own child in the household. The error terms $\varepsilon_{i t}$ and $\omega_{i t}$ are assumed to have a bivariate normal distribution with correlation $\rho$ and respective standard deviations $\sigma_{\epsilon}$ and 1 . The latter variance is normalized to one for identification of the probit choice equation. Column (7) of Table 13 presents the estimates that when the unemployment rate goes up by 1 percentage point, postgraduates face a $0.84 \%$ wage increase relative to undergraduates, which is similar to the baseline.

\section{B.2 Regressions by Industries and Occupations}

Does this phenomenon occur because postgraduates and undergraduates sort into different industries and occupations that are subject to different cyclical variation in productivity? To test whether this argument holds, I run the wage equation at the industry and occupation level. Table 14 presents the estimates. I find that the postgraduate wage premium is counter-cyclical in 
all major industries and in Managerial, Professional Specialty, Technical, and Sales occupations (added up to $82 \%$ of all college graduates).

\section{Importance of Occupations and Industries}

Here I check whether the different wage cyclicality of occupations and industries are important determinants of the counter-cyclical postgraduate wage premium. In order for this argument hold, occupations and industries must be strong predictors of counter-cyclical postgraduate wage premium. To test this condition, I run the following regression

$$
\ln W_{i t}=\sum_{j=1}^{J}\left(\kappa_{j} I_{i j t}+\alpha_{j} I_{i j t} \times U_{t}\right)+\gamma P G_{i t} \times U_{t}+\theta P G_{i t}+X_{i} \beta+\varepsilon_{i t}
$$

where $I_{i j t}=1$ if worker $i$ locates in industry or occupation $j$ at time $t . I_{i j t}$ is interacted with the unemployment rate. The interesting question is by how much coefficient $\gamma$ shrinks after I control for the interaction between the unemployment rate and $I_{i j t}$. The more it shrinks, the more industries and occupations can explain, in a regression sense, the counter-cyclicality postgraduate wage premium. Table 15 shows the regression results. Column (1) shows the baseline without controlling for industries or occupations. When I control for 2-digit industries (43 categories) in Column (2), the coefficient $\gamma$ on $P G_{i t} \times U_{t}$ shrinks slightly from 0.0086 to 0.0078 (s.e. 0.0021 ). When I control for 2-digit occupations (60 categories) in Column (3), the coefficient $\gamma$ shrinks to 0.0063 (s.e. 0.0021). In Column (4), I include interactions between 2-digit occupations and industries, and the coefficient $\gamma$ shrinks to 0.0059 (s.e. 0.0020). In Column (5), I include more dis-aggregated 3 -digit industries (237 categories), and the coefficient $\gamma$ shrinks to 0.0065 (s.e. 0.0020). In Column (6), I include 3-digit occupations (384 categories), and the coefficient $\gamma$ shrinks $40 \%$ to 0.0052 (s.e. 0.0020). 
Table 14: Wage Regression at the Industry/Occupation Level

\begin{tabular}{|c|c|c|c|c|c|}
\hline lnWage & URATE & $P G \times U R A T E$ & $\frac{B A_{I}+P G_{I}}{\sum_{I} B A_{I}+P G_{I}}$ & $\frac{P G_{I}}{\sum_{I} P G_{I}}$ & $\frac{P G_{I}}{B A_{I}+P G_{I}}$ \\
\hline \multicolumn{6}{|c|}{ by Industry } \\
\hline Nondurable Mfg. & $\begin{array}{l}-.0121 \\
(.0039)\end{array}$ & $\begin{array}{l}.0163 \\
(.0026)\end{array}$ & $5.95 \%$ & $4.63 \%$ & $29.76 \%$ \\
\hline Durable Mfg. & $\begin{array}{l}-.0152 \\
(.0026)\end{array}$ & $\begin{array}{l}.0126 \\
(.0023)\end{array}$ & $11.51 \%$ & $9.69 \%$ & $32.25 \%$ \\
\hline T.C.U & $\begin{array}{l}-.0080 \\
(.0036)\end{array}$ & $\begin{array}{l}.0103 \\
(.0025)\end{array}$ & $7.25 \%$ & $4.40 \%$ & $23.23 \%$ \\
\hline F.I.R & $\begin{array}{l}-.0186 \\
(.0034)\end{array}$ & $\begin{array}{l}.0101 \\
(.0025)\end{array}$ & $9.54 \%$ & $7.17 \%$ & $28.79 \%$ \\
\hline Services & $\begin{array}{l}-.0139 \\
(.0019)\end{array}$ & $\begin{array}{l}.0082 \\
(.0021)\end{array}$ & $40.79 \%$ & $56.72 \%$ & $53.26 \%$ \\
\hline Trade & $\begin{array}{l}-.0151 \\
(.0032)\end{array}$ & $\begin{array}{l}.0047 \\
(.0026)\end{array}$ & $11.79 \%$ & $5.97 \%$ & $19.40 \%$ \\
\hline Public Admin. & $\begin{array}{l}-.0018 \\
(.0026)\end{array}$ & $\begin{array}{l}.0066 \\
(.0022)\end{array}$ & $8.48 \%$ & $8.59 \%$ & $38.78 \%$ \\
\hline A.M.C & $\begin{array}{l}.0005 \\
(.0047)\end{array}$ & $\begin{array}{l}.0122 \\
(.0029)\end{array}$ & $4.69 \%$ & $2.84 \%$ & $23.15 \%$ \\
\hline \multicolumn{6}{|c|}{ by Occupation } \\
\hline Managerial & $\begin{array}{l}-.0125 \\
(.0019)\end{array}$ & $\begin{array}{l}.0110 \\
(.0021)\end{array}$ & $29.07 \%$ & $27.94 \%$ & $36.81 \%$ \\
\hline Professional & $\begin{array}{l}-.0131 \\
(.0019)\end{array}$ & $\begin{array}{l}.0087 \\
(.0021)\end{array}$ & $36.35 \%$ & $53.56 \%$ & $56.44 \%$ \\
\hline Technical & $\begin{array}{l}-.0087 \\
(.0037)\end{array}$ & $\begin{array}{l}.0056 \\
(.0025)\end{array}$ & $5.48 \%$ & $4.47 \%$ & $31.29 \%$ \\
\hline Sales & $\begin{array}{l}-.0121 \\
(.0034)\end{array}$ & $\begin{array}{l}.0065 \\
(.0026)\end{array}$ & $11.06 \%$ & $5.32 \%$ & $18.44 \%$ \\
\hline Service \& Admin. & $\begin{array}{l}-.0105 \\
(.0029)\end{array}$ & $\begin{array}{l}.0006 \\
(.0025)\end{array}$ & $9.98 \%$ & $5.29 \%$ & $20.30 \%$ \\
\hline P.C.R & $\begin{array}{l}-.0126 \\
(.0044)\end{array}$ & $\begin{array}{l}.0007 \\
(.0031)\end{array}$ & $4.13 \%$ & $1.71 \%$ & $15.88 \%$ \\
\hline O.F.L & $\begin{array}{l}-.0067 \\
(.0049)\end{array}$ & $\begin{array}{l}-.0071 \\
(.0033)\end{array}$ & $3.94 \%$ & $1.70 \%$ & $16.53 \%$ \\
\hline
\end{tabular}

$\frac{B A_{I}+P G_{I}}{\sum_{I} B A_{I}+P G_{I}}$ : the proportion of Industry/Occupation I among all college graduates $(\mathrm{PG}+\mathrm{BA})$.

$\frac{P G_{I}}{\sum_{I} P G_{I}}$ : the proportion of Industry/Occupation I among all postgraduates. $\frac{P G_{I}}{B A_{I}+P G_{I}}$ : the ratio of postgraduates to college graduates in Industry/Occupation I. T.C.U: Transportation, Communications and Utilities. F.I.R: Finance, Insurance and Real Estate. A.M.C: Agriculture, Mining and Construction. P.C.R: Precision production, Craft and Repair. O.F.L: Operators, Fabricators and Labourers. 
Table 15: Controlling for interaction between the unemployment rate and $I_{i j t}$

\begin{tabular}{lcccccc}
\hline $\ln$ Wage & $(1)$ & $(2)$ & $(3)$ & $(4)$ & $(5)$ & $(6)$ \\
\hline URATE & -.0124 & & & & & \\
& $(.0012)$ & & & & & \\
$P G \times$ URATE & .0086 & .0078 & .0063 & .0059 & .0065 & .0052 \\
& $(.0021)$ & $(.0021)$ & $(.0021)$ & $(.0020)$ & $(.0020)$ & $(.0020)$ \\
2-digit Ind. & & $\checkmark$ & & & & \\
2-digit Occ. & & & $\checkmark$ & & & \\
2-digit Occ. $\times$ Ind. & & & & $\checkmark$ & & \\
3-digit Ind. & & & & & $\checkmark$ & $\checkmark$ \\
3-digit Occ. & & & & & & $\checkmark$ \\
\hline
\end{tabular}

\section{B.3 Change in Log Wages}

Figure 4 plots the average annual changes in log wages between booms and recessions. I use March CPS 1976-2016 and recessions years are 1980-1983, 1990-1992, 2001-2002 and 2008-2010. The figure shows a considerable difference in wage growth rates between undergraduates and postgraduates. Undergraduates have a larger wage growth rate than postgraduates in booms and a smaller (even negative) wage growth rate than postgraduates in recessions. The wage growth rates in booms and recessions for postgraduates are relatively more stable than those for undergraduates.

\section{Model Appendix}

\section{C.1 Unique Search Market}

The definition of equilibrium can be collapsed to the problem:

$$
\max _{\hat{\theta}_{z}^{h}, \mathbb{E}_{z} \hat{V}_{0 z^{\prime}}^{h}} \mu\left(\hat{\theta}_{z}^{h}\right) \mathbb{E}_{z}\left(\hat{V}_{0 z^{\prime}}^{h}-U_{z^{\prime}}^{h}\right)
$$




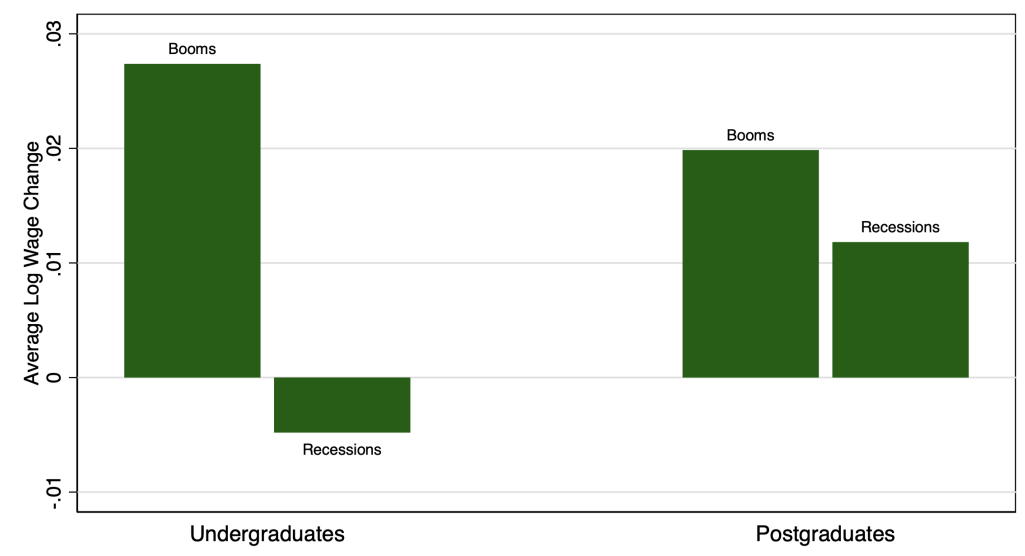

Figure 4: Change in log wages: Booms versus Recessions

s.t.

$$
\beta q\left(\hat{\theta}_{z}^{h}\right) \cdot \mathbb{E}_{z} \Pi^{h}\left(0, z^{\prime}, \hat{V}_{0 z^{\prime}}^{h}\right)-\eta^{h}=0
$$

From the relationship between the probabilities of finding a job and filling a vacancy (Equation 8), we have the job finding rate in a sub-market $\left(\hat{\theta}_{z}^{h}, \mathbb{E}_{z} \hat{V}_{0 z^{\prime}}^{h}\right)$ as follows:

$$
\mu\left(\hat{\theta}_{z}^{h}\right)=\left(\frac{\beta \mathbb{E}_{z} \Pi^{h}\left(0, z^{\prime}, \hat{V}_{0 z^{\prime}}^{h}\right)}{\eta^{h}}\right)^{\frac{\alpha}{1-\alpha}}
$$

Substitute it into (20), we have

$$
\max _{\hat{\theta}_{z}^{h}, \mathbb{E}_{z} \hat{V}_{0 z^{\prime}}^{h}}\left(\frac{\beta \mathbb{E}_{z} \Pi^{h}\left(0, z^{\prime}, \hat{V}_{0 z^{\prime}}^{h}\right)}{\eta^{h}}\right)^{\frac{\alpha}{1-\alpha}} \mathbb{E}_{z}\left(\hat{V}_{0 z^{\prime}}^{h}-U_{z^{\prime}}^{h}\right)
$$

For any contract delivering a higher value to the worker, the market tightness must be lower for firms to break even in offering such a contract. The lower market tightness makes the contract less attractive to workers because their job-finding probability is lower. As the contract value for the worker 
rises, the declining job-finding probability eventually begins to dominate the rising contract value, and a unique optimal level of promised value balances these effects. Therefore, there is a unique equilibrium search market for each $(z, h)$.

\section{C.2 Proof of Lemma 1}

Let's consider two distinct values of aggregate productivity $z_{1}<z_{2}$. At $z_{2}$, the firm can adopt the optimal contract at $z_{1}$, which is feasible and delivers the same value $V$ to the worker. As the transition matrix of $z$ is assumed to be monotone ${ }^{23}$, this strategy generates a higher expected profit than $\Pi^{h}\left(s, z_{1}, V\right)$ - the pareto frontier at $z_{1}$. As this strategy has to be at most equal to $\Pi^{h}\left(s, z_{2}, V\right)$ - the pareto frontier at $z_{2}$, we have that $\Pi^{h}\left(s, z_{1}, V\right)<\Pi^{h}\left(s, z_{2}, V\right)$.

\section{C.3 Proof of Proposition 1}

The first-order conditions for firm problem are

$$
\begin{gathered}
\beta \mathbb{E}_{s z} \Pi^{h}\left(s^{\prime}, z^{\prime}, V_{s^{\prime} z^{\prime}}^{h}\right)=\eta c^{\prime \prime}(e) \\
\frac{\partial e \mathbb{E}_{s z} \Pi^{h}\left(s^{\prime}, z^{\prime}, V_{s^{\prime} z^{\prime}}^{h}\right)}{\partial V_{s^{\prime} z^{\prime}}^{h}}+e w_{s z}^{\gamma}+\eta=0
\end{gathered}
$$

where $\eta$ is the multiplier on the incentive-compatibility constraint. The envelope condition is

$$
\frac{\partial \Pi^{h}(s, z, V)}{\partial V}=-w_{s z}^{\gamma}
$$

\footnotetext{
${ }^{23} \mathrm{~A}$ transition matrix is called monotone if each row stochastically dominates the row above.
} 
From (23) and (24) I obtain

$$
-\frac{\partial e \mathbb{E}_{s z} \Pi^{h}\left(s^{\prime}, z^{\prime}, V_{s^{\prime} z^{\prime}}^{h}\right)}{\partial V_{s^{\prime} z^{\prime}}^{h}}-e w_{s z}^{\gamma}=\frac{\beta \mathbb{E}_{s z} \Pi^{h}\left(s^{\prime}, z^{\prime}, V_{s^{\prime} z^{\prime}}^{h}\right)}{c^{\prime \prime}(e)}
$$

From envelope condition (25), I substitute the first term on the left with the wage next period and get Equation (13).

\section{C.4 Proof of Lemma 2}

In the model, a higher level of specific capital is equivalent to a higher initial productivity gap $\tau$ and a lower upgrading probability $\phi$. Let's consider two distinct levels of specific capital $\xi_{1}=\left(\tau_{1}^{h}, \phi_{1}^{h}\right)$ and $\xi_{2}=\left(\tau_{2}^{h}, \phi_{2}^{h}\right)$. $\xi_{2}$ represents a higher level of specific capital comparing to $\xi_{1}$, i.e. the initial productivity gap $\tau_{2}^{h}>\tau_{1}^{h}$, and the upgrading probability $\phi_{2}^{h}<\phi_{1}^{h}$. From Equation (5), we have the expected firm profit from hiring a trainee

$\Pi^{h}\left(0, z, V ; \xi_{i}\right)=h z-\tau_{i}^{h}-w+\beta e \mathbb{E}_{z}\left[\phi_{i}^{h} \Pi^{h}\left(1, z^{\prime}, W_{1 z^{\prime}}\right)+\left(1-\phi_{i}^{h}\right) \Pi^{h}\left(0, z^{\prime}, W_{0 z^{\prime}}\right)\right]$

At $\xi_{1}$ - the lower level of specific capital, the firm can adopt the optimal contract at $\xi_{2}$, which is feasible and delivers the same value $V$ to the trainee. Due to more output and higher upgrading probability from trainees to skilled workers, this strategy generates a higher expected firm profit than $\Pi^{h}\left(0, z, V ; \xi_{2}\right)$ - the pareto frontier at $\xi_{2}$. As this strategy has to be at most equal to $\Pi^{h}\left(0, z, V ; \xi_{1}\right)$ - the pareto frontier at $\xi_{1}$, we have that $\Pi^{h}\left(0, z, V ; \xi_{2}\right)<\Pi^{h}\left(0, z, V ; \xi_{1}\right)$.

\section{C.5 Proof of Proposition 2}

From Lemma 2, the expected profit from a new job next period (matched with a trainee) $\mathbb{E}_{z} \Pi^{h}\left(0, z^{\prime}, \hat{V}_{0 z^{\prime}}^{h}\right)$ at $\xi_{2}$ is smaller than that at $\xi_{1}$ in every queue in the search market. From Equation (21), the job finding rate in a 
sub-market $\left(\hat{\theta}_{z}^{h}, \mathbb{E}_{z} \hat{V}_{0 z^{\prime}}^{h}\right)$ is an increasing function of $\mathbb{E}_{z} \Pi^{h}\left(0, z^{\prime}, \hat{V}_{0 z^{\prime}}^{h}\right)$. Then, more specific capital reduces a firm's incentive to post vacancies, leading to a decrease in the job finding rate in every sub-market. Thus, the unique equilibrium search markets for each $(z, h)$ at $\xi_{2}$ offers a lower value than that at $\xi_{1}$. This is consistent with Becker (1962) that costs of acquiring specific capital are shared between workers and firms. Therefore, by Equation (12), the value of the worker's outside options at $\xi_{2}$ is lower than that at at $\xi_{1}$. Finally, by Equation (4), as the effort cost function is increasing and strictly convex, the optimal effort level of skilled workers at $\xi_{2}$ is lower than that at $\xi_{1}$.

\section{C.6 Wage-tenure Profiles}

Different levels of specific capital also have different implications for wagetenure profiles. These implications can be summarized by plotting the wagetenure profiles by education, which are displayed in Figure 5. The solid line depicts the postgraduate wage against current job tenure, and the dashed line depicts the undergraduate wage. As each series is logged and demeaned, the results show the percentage deviation from the mean. For both education groups, the wage-tenure profiles are upward sloping. The gap between the starting wage of postgraduates and their average wage is greater than that of undergraduates. ${ }^{24}$ This can also be seen in the column "Baseline" of Table 11, where the percent wage loss after displacement for postgraduates is 0.176 , and that for undergraduates is about -0.089 . The third row of column "Low Capital" of Table 11 shows that when postgraduates have the same low level of specific capital as undergraduates, the immediate wage loss after displacement changes from -0.176 to -0.083 , which is almost the same to undergraduates.

\footnotetext{
${ }^{24}$ The starting wage is the wage of the first month of the new job.
} 


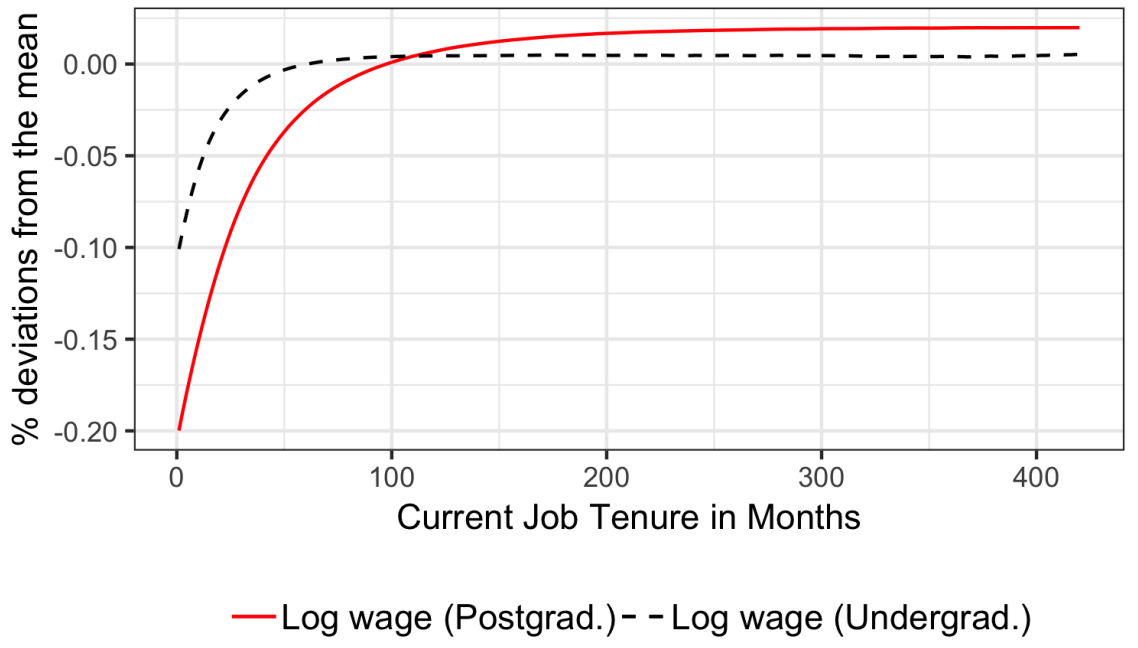

Figure 5: Compare Wage-tenure Profiles by Education

Figure 5 also shows that wage growth is rapid during the early stage of employment, and is faster for postgraduates than that for undergraduates. In fact, the first year of job tenure raises the postgraduate wage by 7 percent and the undergraduate wage by 5 percent, and the first 10 years (120 months) of job tenure raise the postgraduate wage by 21 percent and the undergraduate wage by 11 percent. ${ }^{25}$ Hence, as postgraduates have more specific capital, their starting wage on a new job is relatively low, but subsequent wage growth is faster.

\section{Evaluating Other Potential Explanations}

This section evaluates the plausibility of other potential explanations for the counter-cyclical postgraduate wage premium.

\footnotetext{
${ }^{25}$ Topel (1991) estimates that 10 years of job tenure raise the wage by $25 \%$. Altonji and Williams (2005) place the tenure effect on wages at $11 \%$ per decade.
} 


\section{D.1 Relative Supply}

One possibility for why the postgraduate wage premium is counter-cyclical is that the relative supply of postgraduates to undergraduates declines in recessions, and thus, the postgraduate wage increases relative to the undergraduate wage. Therefore, I test whether the relative supply of postgraduates to undergraduates is pro-cyclical.

Figure 6 plot the detrended real GDP and the relative supply of postgraduates to undergraduates. I restrict the sample to male workers aged 26-64. To detrend, I use a Hodrick-Prescott (HP) filter with parameter 100. NBER dated recessions are shaded. The relative supply of postgraduates to undergraduates increases in all of the recessions except the recent Great Recession, and its correlation with real GDP is -0.32 , indicating that the relative supply of postgraduates to undergraduates is counter-cyclical.

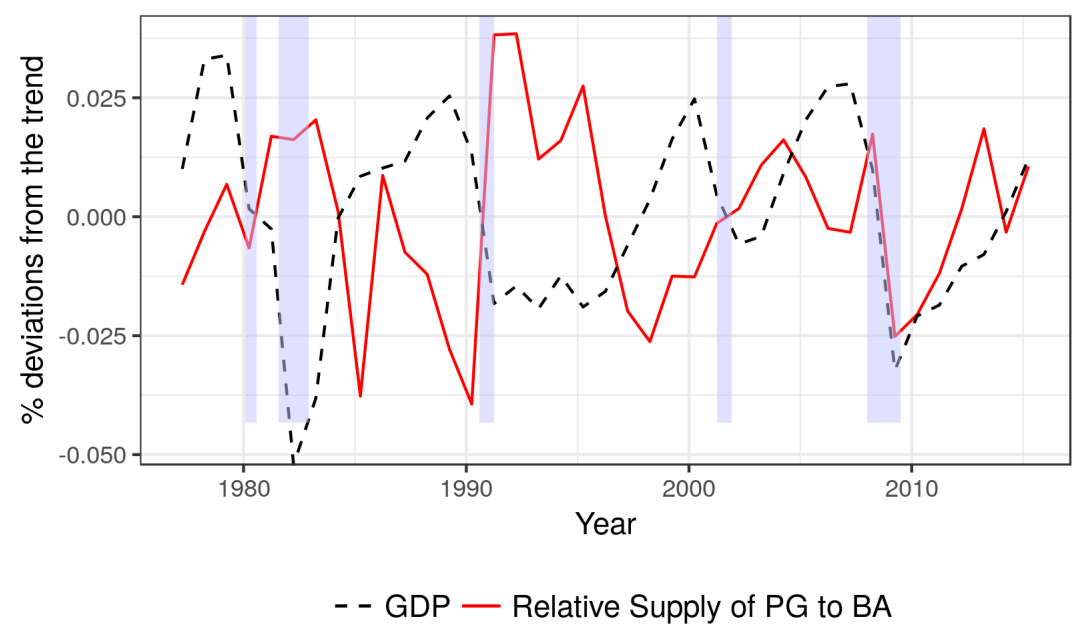

Figure 6: Detrended Real GDP and the Relative Supply of PG to BA NBER recessions are shaded. Series are logged and detrended using a HodrickPrescott (HP) filter with parameter 100. 


\section{D.2 Differences in the Profitability of Jobs}

A possible explanation for why postgraduates have smaller cyclical wage shocks than their undergraduate counterparts might be related to the higher profitability of their jobs. In the terminology of search models, postgraduates might have a lower flow value of unemployment. In my baseline simulation, I ruled out this possibility by assuming the proportionality between the flow value of unemployment and the amount of general skills across education groups in Equation 18.

Here I relax the proportionality assumption between postgraduates and undergraduates. To test this hypothesis, I first assign postgraduates and undergraduates the same level of specific capital. Then, instead of assuming the flow value of unemployment for postgraduates as $b^{P G}=b * h_{P G}=0.557 *$ $1.222=0.681$, I search for the value of $b^{P G}$ that generates the empirical elasticity of postgraduate wage to GDP. I find $b^{P G}=0.172$, which is smaller than that in the baseline. The simulation results, reported in the column "Profit" of Table 16, indicate that postgraduates have less wage cyclicality than undergraduates. However, the model now counterfactually predicts higher job finding rates for postgraduates than undergraduates. Intuitively, since postgraduate jobs yield higher profit, firms are willing to post more vacancies in this segment of the labour market, leading in turn to higher labour market tightness and job finding rates.

\section{D.3 Differences in Hiring Costs}

Another possible explanation might be that postgraduates have higher hiring costs. In my baseline simulation, I already assumed that the vacancy posting cost grew proportionally with the amount of general skills in Equation 17. However, it might understate the true differences in hiring costs between postgraduates and undergraduates. 
Table 16: Other Potential Explanations

\begin{tabular}{lcccc}
\hline Moments & Data & Baseline & Profit & Hiring \\
\hline Postgraduates & & & & \\
$\quad$ Job separation rate & .005 & .005 & .005 & .004 \\
Job finding rate & .245 & .248 & .351 & .099 \\
$\quad$ Elasticity of median wage to GDP & .34 & .322 & .34 & .34 \\
\hline Undergraduates & & & & \\
$\quad$ Job separation rate & .009 & .009 & .009 & .009 \\
$\quad$ Job finding rate & .263 & .263 & .263 & .263 \\
$\quad$ Elasticity of median wage to GDP & .58 & .58 & .58 & .58 \\
\hline
\end{tabular}

I assign postgraduates and undergraduates the same level of specific capital. I search for the value of $\eta^{P G}$ that generates the empirical postgraduate wage elasticity instead of assuming proportionality, i.e. $\eta^{P G}=\eta * h_{P G}=$ $7.324 * 1.222=8.95$. I find $\eta^{P G}=516$, which is much larger than that in the baseline. The simulation results, reported in the column "Hiring" of Table 16 , indicate that postgraduates have less wage cyclicality than undergraduates. However, the model now counterfactually predicts much lower job finding rates for postgraduates than the data predict. Intuitively, since it is costlier to hire postgraduates, firms will post fewer vacancies in this labour market segments. As a result, their job finding rate drops. 